NBER WORKING PAPER SERIES

\title{
REVISITING THE INCOME EFFECT: GASOLINE PRICES AND GROCERY PURCHASES
}

\author{
Dora Gicheva \\ Justine Hastings \\ Sofia Villas-Boas \\ Working Paper 13614 \\ http://www.nber.org/papers/w13614 \\ NATIONAL BUREAU OF ECONOMIC RESEARCH \\ 1050 Massachusetts Avenue \\ Cambridge, MA 02138 \\ November 2007
}

We thank Daron Acemoglu, Severin Borenstein, Keith Chen, J.P. Dube, Matthew Gentzkow, Eric Hurst, George Judge, Aviv Nevo, Sharon Oster, Jon Quinn, Sergio Rebelo, Fiona Scott-Morton, Jesse Shapiro, Matt Turner and participants at the Yale Macroeconomics Workshop, the Yale Industrial Organization Lunch and the New York Federal Reserve Workshop for helpful comments. We thank Rosangela Bando, Joshua Berning, Grant Chen, Melissa Hidrobo, Kristin Kiesel, Quoc Luong, and Bruno Romani for help conducting the store survey and Steve Flaming for help with the scanner data. The views expressed herein are those of the author(s) and do not necessarily reflect the views of the National Bureau of Economic Research.

(C) 2007 by Dora Gicheva, Justine Hastings, and Sofia Villas-Boas. All rights reserved. Short sections of text, not to exceed two paragraphs, may be quoted without explicit permission provided that full credit, including $\odot$ notice, is given to the source. 
Revisiting the Income Effect: Gasoline Prices and Grocery Purchases

Dora Gicheva, Justine Hastings, and Sofia Villas-Boas

NBER Working Paper No. 13614

November 2007

JEL No. E21,E31,L10,L16,L81

\begin{abstract}
This paper examines the importance of income effects in purchase decisions for every-day products by analyzing the effect of gasoline prices on grocery expenditures. Using detailed scanner data from a large grocery chain as well as data from the Consumer Expenditure Survey (CES), we show that consumers re-allocate their expenditures across and within food-consumption categories in order to offset necessary increases in gasoline expenditures when gasoline prices rise. We show that gasoline expenditures rise one-for-one with gasoline prices, consumers substitute away from food-away-from-home and towards groceries in order to partially offset their increased expenditures on gasoline, and that within grocery category, consumers substitute away from regular shelf-price products and towards promotional items in order to save money on overall grocery expenditures. On average, consumers are able to decrease the net price paid per grocery item by $5-11 \%$ in response to a $100 \%$ increase in gasoline prices. Our results show that consumers respond to permanent changes in income from gasoline prices by substituting towards lower-cost food at the grocery store and lower priced items within grocery category. The substitution away from full-priced items towards sale items has implications for microeconomic discrete-choice demand models as well as for macroeconomic inflation measures that typically do not incorporate frequently changing promotional prices.
\end{abstract}

Dora Gicheva

Yale University

P.O. Box 208264

New Haven, CT 06520-8264

dora.gicheva@yale.edu

Justine Hastings

Yale University

P.O. Box 208264

New Haven, CT 06520-8264

and NBER

justine.hastings@yale.edu
Sofia Villas-Boas

UC, Berkeley

Department of Agricultural \& Resource Economics

310 Giannini Hall

CA 94720-3310

sberto@are.berkeley.edu 
As many drivers struggle to cope with soaring fuel prices, working-class people like Ms. Lopez who commute long distances to their jobs are suffering the most..... Ms. Lopez looks for weekly specials at the supermarket. Salmon, her favorite fish is $\$ 7$ a pound these days. So she buys the tilapia for $\$ 2.99$ instead.

-- Full Tanks Put Squeeze on Working Class, NY Times, May 13, 2006

\section{Introduction}

The extent to which relatively small income shocks change consumer purchase behavior has significant implications for our understanding of business cycles, fiscal policy and the macro economy. For example, some argue that increases in oil prices may lead to recessions through an income effect on overall consumption (Hamilton, 1983). ${ }^{1}$ If spikes in gasoline prices significantly decrease disposable income, and if consumers react by curbing expenditures in other categories, then oil prices may have a significant impact on the macro-economy through their effect on consumption. Several recent studies present empirical evidence that households do not smooth consumption over income fluctuations, but instead adjust current consumption to changes in current income more than would be expected under the Permanent Income Hypothesis (Poterba, 1988; Shapiro and Slemrod, 1995; Parker, 1999; Mankiw, 2000; Stephens, 2003; Cullen et al., 2004; Shapiro, 2005; and Card et al., 2006). This paper uses data from the Consumer Expenditure Survey (CES) and detailed scanner data from a large grocery retail chain in California to examine if and how consumers adjust every day purchases in response to relatively small changes in disposable income caused by sharp increases in gasoline prices. We find that consumers re-allocate their expenditures across and within food-consumption categories in order to offset necessary increases in gasoline expenditures when gasoline prices rise,

\footnotetext{
${ }^{1}$ Other mechanism through which oil prices may affect GDP focus on the role of oil as an input to production in a variety of sectors of the economy (Rotemberg and Woodford,1996; Hamilton, 1983), or the price of oil as a factor that affects investment and value added through increased uncertainty (Bernanke, 1983). Barsky and Killian (2004) summarize the empirical evidence suggesting that oil prices spikes cause recessions, and the mechanisms through which this effect might occur.
} 
as we might expect under the Permanent Income Hypothesis when gasoline prices follow a random walk.

From 2000 through 2005 gasoline prices were very volatile, following a random walk that ranged from less than $\$ 1.50$ to around $\$ 3.00$ per gallon. We first use data from the CES to examine how gasoline prices affect reported gasoline expenditures and expenditures on frequently purchased categories such as food-away-from-home and groceries. CES data imply that gasoline purchases constitute a significant fraction of household expenditures, and most empirical estimates show that gasoline demand is extremely price inelastic (Dahl and Sterner, 1991; Espey, 1998; Puller and Greening, 1999; Nicol, 2003; Hughes, et al., 2006). Using data from the detailed diary files we find that gasoline expenditures increase one for one with gasoline prices. Hence, for a household that spends $5 \%$ of disposable income on gasoline, a doubling of gasoline prices would lead to a $5 \%$ decrease in disposable income available for other weekly purchases such as groceries, restaurants and entertainment.

Using the CES data we find that food expenditures away from home decrease significantly when gasoline prices rise, with a $45-56 \%$ decline in expenditures on foodaway-from-home associated with a $100 \%$ increase in gasoline prices. Although consumers appear to decrease expenditures on food-away-from-home, we find that these savings are partially offset by increases in food purchased at grocery stores. We find a positive but marginally significant increase of $15-19 \%$ in grocery food expenditures for a $100 \%$ increase in gasoline prices. Hence consumers appear to substitute away from more expensive expenditures on food-away-from-home towards less expensive grocery purchases in order to reduce expenditures on food consumption when expenditures on gasoline rise.

Although the analysis using the CES data tells an interesting story of how consumers may adjust food expenditures in response to income shocks caused by gasoline price spikes, the story is incomplete. The CES data contain relatively small samples and do not have the detail necessary to examine how consumers adjust what they buy at the grocery store 
when gasoline prices increase. Hence we turn to detailed scanner data from a large grocery retailer in California to examine if the suggestive patterns in CES data are born out in grocery purchases, and how consumers adjust what they buy within grocery categories in response to income shocks. We use weekly store-level data on revenues and sales from 180 West Coast grocery stores for products (UPCs) in frequently purchased consumer food categories. We find that consumers adjust to higher gasoline prices by substituting within category towards products that are on sale: the fraction of purchases within a product category from items on sale increases significantly with gasoline prices. We also show that on average, quantity-weighted price paid for products decreases when gasoline prices increase, so consumers save money on groceries by shifting purchases towards promotional items. Using data from the grocery retailer on consumer-level demographics for each store, we show that this effect is generally strongest for stores serving lower-income families and weakest for those serving high-income households.

Overall, we find evidence that consumers significantly adjust food consumption to reduce expenditures in response to decreases in disposable income caused by gasoline price increases. Our approach provides a number of benefits for identifying the effect of small changes in disposable income on consumer purchase behavior. First, gasoline demand is very inelastic, so increases in gasoline prices translate directly into decreases in income available for other expenditures. Second, since gasoline is not a substitute for grocery products, finding an effect of gasoline prices on product choice for a category such as cereal can be attributed to an income rather than a substitution effect. Third, gasoline prices are arguably exogenous to local store product selection, to changes in relative prices within product categories (e.g. the price of Corn Flakes versus Wheaties), and to other inter-temporal or idiosyncratic shocks to household income. They also follow a particular pattern of spikes and troughs in California over the three years in our analysis, reducing the chance that any identified effect of gasoline prices on grocery purchases could be caused by other potentially confounding trends in household preferences or income levels over time. 
Our results imply that changes in income affect every-day purchase decisions. A back-ofthe-envelope calculation based on our results implies that consumers offset about $70 \%$ of the increased expenditures when gasoline prices double by substituting away from eating out towards groceries and by substituting towards promotional items at the grocery store. Since food expenditures are approximately $20 \%$ of total expenditures (from CES data), this implies a more-than-proportional income effect in this category relative to other expenditure categories that may be less easily adjusted in the short-run such as mortgage, gasoline expenditures, and car payments (Chetty and Szeidl, 2007). Typical discretechoice demand models abstract from income effects when modeling purchase decisions in relatively small-priced product categories like groceries. Although an individual grocery product's price is small in comparison to overall income, grocery expenditures may be one of the easiest margins on which to adjust expenditures in response to unexpected changes in permanent income, hence grocery product choice may be one of the most sensitive rather than least sensitive expenditures to income shocks in the shortrun. In addition, the ability of consumers to significantly decrease expenditures by simply substituting towards promotional items suggests that measures of inflation that do not flexibly incorporate sale and promotional prices may not fully capture changes in overall cost of consumption.

\section{Gasoline Prices, Income, and Food Expenditures in the CES}

Gasoline prices have increased dramatically several times over the past five years. This volatility has been particularly prominent in California markets where gasoline prices have spiked due not only to spikes in crude oil prices, but also due to regional supply shortages from refinery outages and other supply disruptions. ${ }^{2}$ In addition, run-ups in gasoline prices are often more severe than in other regions of the country even when caused by the same underlying changes in crude oil prices. From 2000 through the end of 2005, California gasoline markets experienced several large increases in gasoline prices.

\footnotetext{
${ }^{2}$ California requires its own formulation of gasoline to meet California Air Resources Board emissions standards. This formulation is not required in other regions of the country, separating California to some degree from gasoline supply in the rest of the nation.
} 
Figure I plots weekly average retail prices for regular unleaded gasoline for California, the West Coast excluding California, and the United States as a whole. ${ }^{3}$ It also plots the price of crude oil in dollars per gallon. ${ }^{4}$ A few things are important to note. First, there are several instances in which gasoline prices increase by over 25\%. Moreover, these spikes are strongest in California, and many of the California price spikes do not appear to be linked to changes in crude oil prices, but rather to temporary regional supply shocks. Second, the pattern of spikes and troughs is particular to gasoline prices, and most likely exogenous to other factors that affect household income or household product preferences. If these spikes translate into real changes in disposable income, then we will be able to examine the effect of these income fluctuations on consumer expenditures, controlling for trends and seasonal effects that may affect food expenditures and grocery purchases. We test if gasoline prices during this time period follow a random walk using an augmented Dickey-Fuller test and cannot reject that the time series follows a random walk, implying that consumer's best prediction of future gasoline prices are today's gasoline prices. ${ }^{5}$ Thus, changes in gasoline prices translate into changes in permanent income available for expenditures in other categories.

How might a 50\% increase in gasoline prices affect household disposable income? In order to calculate this we need to know how much a typical household spends on gasoline, and how gasoline prices affect total gasoline expenditures. Table I provides summary statistics on household expenditures by category taken from the Consumer Expenditure Survey (CES) for respondents in the West Coast region and in California respectively. ${ }^{6}$ We use the CES detailed diary files which provide data on weekly expenditures for relatively narrow subcategories of products and services (e.g. gasoline,

\footnotetext{
${ }^{3}$ These data come from the Energy Information Administration website www.eia.doe.gov. The data are for regular unleaded gasoline for all formulations in the West Coast (PADD 5) and the U.S., and for regular unleaded reformulated gasoline in California.

${ }^{4}$ Crude oil prices are the weekly spot price at WTI: Cushing, Oklahoma, as posted by the Energy Information Administration.

${ }^{5}$ The reported Dickey-Fuller test statistics was -0.978 , and the MacKinnon approximate p-value for the unit root test was 0.7613 .

${ }^{6}$ The "West" geographic region consists of Alaska, Arizona, California, Colorado, Hawaii, Idaho, Montana, Nevada, New Mexico, Oregon, Utah, Washington, and Wyoming. The CES data contain a flag for urban or rural residence and a state Federal information processing standards (FIPS) code for each respondent. In order to preserve confidentiality the state FIPS code is suppressed for some respondents. In our calculations, we count any respondents with a state FIPS code for California as a California resident.
} 
food-away-from-home, alcoholic beverages). This survey is specifically designed to track expenditures of approximately 200 households per week across the entire U.S. Each household stays in the survey for only two weeks, so the sample frame is a repeated cross-section. During the two consecutive weeks respondents are interviewed and asked to fill out detailed forms that break down their expenditures by category for each of the two weeks. A new sample of the population is drawn for each interview period. The sample is relatively small, but is designed to be reflective of the overall population. In order to construct aggregate expenditure statistics for Table I from the diary files, we add up expenditures for each consumer over the two survey weeks. Since reported income is annual, we divided this number by 26. Dividing expenditures by this bi-weekly income variable allows us to obtain expenditures as a share of after-tax income as reported in Table I. ${ }^{7}$

Table I suggests that gasoline accounts for a significant part of expenditures, especially for people in lower income categories. For example, Panel A of Table I, which provides statistics for respondents in the "West" geographic region, shows that in 2002 the average consumer spent $3.37 \%$ of their income on gasoline. This number is almost double, $6.21 \%$ for consumers in the lowest quintile of the income distribution. If we calculate gasoline expenditures as a percent of disposable income (income after mortgage or rent) then gasoline expenditures account for $4.5 \%$ and $12.4 \%$ of disposable income for the average respondent and the average respondent in the lowest income quintile respectively. For Californians in Panel B, whose average share of income devoted to gasoline expenditures is both higher than respondents in other states, these numbers are $5.1 \%$ and $13.3 \%$ respectively.

Because gasoline consumption is very inelastic in the short run, changes in gasoline prices translate directly into changes in gasoline expenditures. Table II presents regression results of gasoline expenditures on gasoline prices using the CES detailed diary files data for consumers in West Coast markets for 2000-2004 (the most recent years available). Since we do not know the exact price respondents in CES paid for

\footnotetext{
${ }^{7}$ We only include consumers that the survey identifies as complete income respondents.
} 
gasoline, we use weekly regional average gasoline prices for regular unleaded gasoline as reported by the Energy Information Administration as our measure of the price paid for gasoline. We use the West Coast (PADD 5) excluding California average retail gasoline price for all formulations, regular unleaded gasoline for respondents who did not live in California, and the California retail average price for regular unleaded reformulated gasoline for respondents with state FIPS code for California. ${ }^{8}$ Table II presents weighted least squares regression of log gasoline expenditures on log gasoline prices, controlling for demographic variables such as income and its square, number of vehicles in the household and its square, race, gender and employment status. ${ }^{9}$ The regression controls also include monthly dummies, yearly dummies and a time trend. The results in Table II imply that gasoline expenditures increase $100 \%$ when gasoline prices increase by $100 \%$. The exact point estimates are 1.03 and 1.05 for the entire sample and for urban households respectively, and both are significant at less than 0.01 level. ${ }^{10}$

Given that gasoline expenditures rise exactly with gasoline prices, we would expect a $100 \%$ increase in gasoline prices to decrease the disposable income available for other purchases by $100 \%$ of baseline gasoline expenditures. Recent empirical research has shown using expenditure data, consumption data, and data on instantaneous consumption that consumers do not smooth consumption over changes in income or over income cycles as would be predicted by the Permanent Income Hypothesis (Poterba, 1988; Parker, 1999; Stephens, 2003; Cullen et al., 2004; Shapiro, 2005) ${ }^{11}$ Potential reasons for excess sensitivity of current consumption to current income include liquidity constraints (Deaton, 1991; Gruber, 1997; among others), consumer myopia (Shapiro and Slemrod, 1995; Mankiw, 2000; Card, et al. 2006), impatience (Shapiro, 2005) and mental

\footnotetext{
${ }^{8}$ The EIA reports several gasoline price statistics for West Coast markets. Geographically they report a CA average, a West Coast without CA average, and an entire West Coast average. We use the first two of these statistics. The West Coast is defined by PADD 5 boundaries and includes the states Alaska, Arizona, California, Hawaii, Nevada, Oregon, and Washington. We use the average price for regular unleaded gasoline for all formulations.

${ }^{9}$ Weights are given by the Consumer Expenditure Survey.

${ }^{10}$ We run the estimation separately for urban households since the retail gasoline prices may be more representative of what urban households pay, and because FIPS codes are less likely to be suppressed for urban residents.

${ }^{11}$ In particular, consumption is found to increase due to predictable increases in union wages (Shea, 1995), predictable tax refunds (Souleles, 1999), temporary tax refunds (Shapiro and Slemrod, 1995), and monthly food stamps (Shapiro, 2005).
} 
budgeting (Thaler, 1985; Shapiro and Slemrod, 1995; Heath and Soll, 1996; Read et al., 1999). ${ }^{12}$ However, since gasoline prices follow a random walk, consumption in food categories may be very sensitive to changes in gasoline prices because they are a relatively easy short-term margin to adjust expenditures relative to more 'committed' portions of consumption such as commute patterns, auto fuel efficiency, and mortgage payments (Chetty and Szeidl, 2007).

Table III presents regression results showing how food expenditures change when gasoline prices change. We focus on food expenditures for three reasons. First, they are purchased often, allowing us to have a reasonable sample size for frequent changes in gasoline prices despite the overall small sample in the CES detailed diary files. Second, they represent a relatively large expenditure category (see Table I), and a relatively easy margin on which consumers can adjust weekly expenditures. Third, they allow for a nice comparison with the detailed scanner data in the next section. The first two columns of Table III present regression results for log expenditures for food-away-from-home on log gasoline prices for all respondents and urban respondents respectively. The same controls that were used in the regressions in Table II are also included in these regressions. The results show that expenditures on food-away-from-home decrease by $56 \%$ in the sample and $45 \%$ among urban respondents when gasoline prices increase by $100 \%$. The coefficients are highly significant and imply an economically significant decrease in expenditures on food away from home in response to increases in gasoline prices. Given that the average respondent in California spends $6.86 \%$ of after-tax income on foodaway-from-home (see Table I), decreasing expenditures on food-away-from-home by $56 \%$ translates into savings of almost $4 \%$ of income (5\% of disposable income).

Columns 3 and 4 of Table III show the effect of gasoline prices on expenditures on food purchased at the grocery store for all respondents and urban respondents respectively. ${ }^{13}$

\footnotetext{
${ }^{12}$ Moreover Card, et al (2006) and Shapiro and Slemrod (1995) present empirical estimates and find survey evidence that the percentage of "myopic" consumers is non trivial, and on the order of fifty to seventy percent.

${ }^{13}$ We use the log of weekly expenditure for food and non-alcoholic beverages purchased at grocery store (in the CES diary files called JGRCFDWK) as the dependent variable.
} 
The coefficients imply that grocery purchases increase when gasoline prices increase, although the effect is only significant for urban respondents. The point estimates imply a $15 \%$ and a $19 \%$ increase in grocery expenditures in response to a $100 \%$ increase in gasoline prices. Table I shows that the average household in California spends $11.77 \%$ of income on food from the grocery store, so increasing grocery purchases by $15 \%$ means spending an extra $1.8 \%$ of income (2.4\% of disposable income).

Overall the evidence from CES data implies that gasoline price increases translate directly into gasoline expenditure increases due to the extreme inelasticity of gasoline demand. Since consumers cannot substitute for gasoline, they decrease expenditures on food items in order to make up for increased expenditures on gasoline. Although this finding is another piece of evidence that runs contrary to the Permanent Income Hypothesis, the patterns of substitution seem quite rational. Consumers decrease spending on more expensive and perhaps luxury expenditures on food-away-from-home and substitute towards less expensive food purchased at the grocery store in order to make up for lost income spent on high gasoline prices. Taken together, our estimates imply that when gasoline prices increase by $100 \%$, an average respondent in California who spends $3.7 \%$ of income on gasoline decreases overall food expenditures by $2.2 \%$ of income (a $4 \%$ decline in food away from home plus a 1.8\% rise in grocery expenditures) to offset the necessary doubling of gasoline expenditures.

In order to further understand how consumer behavior changes when disposable income decreases due to increased gasoline prices, we analyze detailed scanner data from a major California retail grocery chain. Scanner data allow us to examine transactions from hundreds of thousands of recorded consumer purchases at the UPC level to see how consumers substitute between grocery products when gasoline prices increase.

\section{Results from Retail Grocery Data}

Our analysis of retail grocery purchases and how they adjust to changes in gasoline prices involves two data sets. The first data set comes from customer surveys conducted at three 
of the grocery stores in our scanner data sample. The second data set is scanner data on four product categories from 180 retail grocery stores in California. The survey information helps us to understand how, if at all, customers perceive that they adjust their grocery purchases when gasoline prices rise. The survey was conducted during the week of November 6, 2006 at three of the grocery stores in our scanner data. The survey collected information on customer demographics, customer commute and gasoline expenditure behavior, and information on their grocery store purchase behavior. ${ }^{14}$ Overall, a total of 1,200 surveys were completed.

\subsection{Survey Analysis}

There were two main questions about behavioral responses to gasoline prices. First, respondents were asked to state how they felt about the following statement: "When gasoline prices are very high, I tend to save money by watching what I buy at the grocery store”. They circled a number from 1 to 7 that corresponded to the degree to which they disagreed or agreed with the statement. Circling a 1 indicated that they strongly disagreed with the statement, circling a 4 meant that they neither agreed nor disagreed, and circling a 7 meant that they strongly agreed. We will refer to this question as Question 1 from here forward. Table IV shows average demographic information for each store as well as the average response to Question $1 .^{15}$ The average response to Question 1 is highest at the low-income store, and lowest at the high-income store. Over the entire sample, about $46 \%$ of respondents agree to some extent that they adjust their grocery purchases when gasoline prices are high (response to Question 1 equal to 5 or higher).

\footnotetext{
${ }^{14}$ The main purpose of the survey was to collect information on consumer purchasing habits and sensitivity to packaging and labeling for a separate study. We added in questions about gasoline prices and grocery purchases to this survey. The grocery stores were chosen to represent a low, middle, and a high income neighborhood. Participants were approached by a surveyor outside of each store, and offered an incentive of a $\$ 10$ store credit to fill out a survey form.

${ }^{15}$ The demographic information collected from the respondents is very similar to demographic information calculated from the census block groups of residence for each store's customers. For example, the average block-group Median Household Income from the 2000 Census is \$56,214, \$68,806, and \$89,697 for customers at the low-, middle-, and high-income stores respectively.
} 
Table V presents logistic regression of an indicator if the response to Question 1 was a 5 or higher (i.e., the customer agreed to some degree with Question 1) on demographics. ${ }^{16}$ Model 1 includes a linear effect of income while Model 2 allows for a spline in income with a break point at the median reported income of $\$ 50,000$. The estimated coefficient on stated household income is negative and significant; decreasing the extent to which the respondent states they adjust grocery expenditures when gasoline prices are high. An increase in income of 1 translates into increase in stated income of $\$ 10,000$. Thus the coefficient on income in Model 1 implies a 2\% decrease in the probability of agreeing with Question $1(-0.01 / 0.46)$ for every $\$ 10,000$ increase in reported income. ${ }^{17}$ Model 2 allows for a different marginal effect of income below and above $\$ 50,000$, and shows that this average $2 \%$ effect of income is generated by a larger significant effect among respondents with above median income. The coefficients imply that income significantly decreases the probability that a respondent agrees with Question 1 only among abovemedian income respondents. The marginal effect of an increase in income of $\$ 10,000$ is 2.7 percentage points which corresponds to a 6 percent decrease in probability of agreeing with Question 1.

The other two significant factors that determine the response to Question 1 are the responses to two questions that attempt to measure how carefully a consumer pays attention to product characteristics (like prices and labels) when purchasing groceries. These questions ask respondents to indicate how much they agree with the statement that they often read the nutritional label when deciding what product to purchase and to what extent they shop at multiple stores to get lower prices. ${ }^{18}$ An increase by 1 in the stated degree to which a customer pays attention to nutritional facts leads to an increase in probability of adjusting groceries purchases of 2.5 percentage points (or a 6\% increase).

\footnotetext{
${ }^{16}$ We also ran models using an ordered logit with the response to Question 1 as the dependent variable and obtained qualitatively similar results.

${ }^{17}$ The coefficients in the logit in Model 1 give the change in the log odds of agreeing with Question 1. Since the mean probability of agreeing with Question 1 is $46 \%$, the coefficient on income implies a 1 percentage point increase in the probability of agreeing with Question 1 when income decreases by $\$ 10,000$ $(-0.040 * 0.46 * 0.54)$.

${ }^{18}$ The exact questions were "In general, how often do you read the NUTRITION FACTS panel that reports nutrient information on food products" (ranked 1-7 for Not Often to Very Often), and "I will grocery shop at more than one store to take advantage of low prices" (ranked 1-7 for Strongly Disagree to Strongly Agree).
} 
An increase by 1 in the extent to which consumers feel they are willing to price shop across stores to get the best price leads to a significant 4.2 percentage points (or roughly $10 \%$ ) increase in the probability of adjusting grocery purchases when gasoline prices rise.

The survey then asked customers questions related to how they adapt their grocery purchases to save money when gasoline prices are high. They were asked to rank from 1 to 7 the extent to which they agreed or disagreed with the following four statements.

"When gasoline prices are very high, I watch what I buy at the store by doing the following:

1. I try to buy the items that are on sale

2. I try to buy the store brand or the generic instead of the brand name item

3. I buy more packaged foods and fewer fresh foods

4. I try to purchase less meat and less prepared foods"

These options were not exhaustive, but were selected based on consumer interviews in media and the press. We will refer to these questions as Questions 2.1, 2.2, 2.3, and 2.4 respectively. Table VI presents summary statistics for Questions 2.1-2.4. Column 1 shows that buying items on sale has the highest average response. The next two columns of Table VI are indicators for the highest mark and lowest mark given by customer across the four questions. ${ }^{19}$ Almost all people ranked buying sale items the highest: the strongest agreement was given to buying sale items for $86 \%$ of respondents. ${ }^{20}$ The next strongest response is for substituting towards store brands and decreasing purchases of meat products, but for these only $45 \%$ and $28 \%$ of respondents (respectively) ranked them highest.

The last two columns of Table VI give the fraction of respondents who agree ( $>4)$ and fraction who disagree $(<4)$, where a response of 4 is excluded. Notice again that buying on sale is the strongest response in terms of those who agree. The agreement rate is $89 \%$. More importantly, a very small fraction (5\%) disagrees to any extent with Question 2.1.

\footnotetext{
${ }^{19}$ Ties for highest would show up for columns with ties: if customer ranks all four possible ways to cut back on grocery expenditures as a 7, then that customer appears as ranking all of them the highest.

${ }^{20}$ Respondents could circle a number greater than 4 for all 4 categories. This measure gives the response with the highest rank out of the 4 .
} 
This measure is similar to measures used in political polling. As important as approval or agreement rating is the fraction of people who disapprove or disagree with a statement. Almost all respondents look for sale items; however there is a sizeable fraction who state that they don't switch to the store brand or to purchasing less meat or packaged products in order to save money on groceries in response to high gasoline prices.

In summary, based on the survey responses, about $46 \%$ of respondents state that they adjust their grocery purchases to save money when gasoline prices are high. ${ }^{21}$ The probability is highest among low-income consumers. Among those who adjust their purchases to save money when gasoline prices are high, the main way they adjust purchases is by purchasing items that are on sale instead of their preferred brand (in the case that they differ). We now analyze the panel of scanner data to see if these patterns are born out in actual consumer purchases.

\subsection{Scanner Data Analysis}

We have access to weekly store-level data for a sample of 180 grocery stores from a retail chain in California. The retailer is a standard grocery store chain and has stores in a broad range of socio-economic neighborhoods. We selected 200 stores at random from the stores in the retail chain, with a higher sampling probability placed on stores in lowincome neighborhoods and those with higher average reported commute times. We dropped stores from the final sample that were not open for our entire observation period or did not have customer-level demographic data. This left us with 180 stores total.

We have access to membership card data for the primary customers of each of our 180 stores, with demographic information on each customer attached to their membership card number. These demographics include household characteristics purchased by the retailer from marketing companies as well as demographic data from the 2000 US Census for each customer's Census block-group of residence. We aggregate the customer data at the store-level to show how customer characteristics vary across the stores in our

\footnotetext{
${ }^{21}$ It is interesting to note that $46 \%$ is roughly in the range of 'myopic' consumers found in various studies in the prior literature (Shapiro and Slemrod, 1995; Mankiw, 2000l; Card , et al. 2006).
} 
sample. ${ }^{22}$ Table VII reports summary statistics for the customer demographics across stores. There is a large variation in income across the stores in our sample, allowing us to test if store-level purchase patterns respond more to gasoline price spikes at stores serving low-income customers.

For each of the stores we have weekly UPC-level data for all items within four product categories. The data include the total unit quantity of each product sold, the total gross revenue, the total revenue net sale discounts, and the total weight sold where needed (for example, pounds of meat where price is measured in dollars per pound). We use these variables to construct the average gross price per week for each UPC, the average price net of discounts per week, and the total volume sold for each UPC in each week. Because the grocery retailer changes promotions and sales on a weekly basis, the aggregated data yield the correct prices and promotional discounts for each weekly observation.

We match weekly average gasoline prices for Los Angeles to weekly measures of consumer purchase behavior in each category. ${ }^{23}$ The average gasoline price in Los Angeles is a good approximation for local prices that customers at our stores face, but is constant across stores, avoiding potential local endogeneity between gasoline prices and grocery sales (i.e. in one neighborhood, gasoline prices are particularly high, causing customers to buy gasoline and groceries in an adjacent neighborhood). If income effects are important, as suggested by survey results, we would expect to see that when gasoline prices are high, consumers purchase a higher fraction of products on sale, and that the quantity weighted net price paid per unit falls.

The first category we examine is all-family cold cereal (cereal from here on). We examine this category because it is a frequently purchased item, has frequent promotions that significantly discount the items, and doesn't have close substitutes. This category

\footnotetext{
${ }^{22}$ Using the demographic information on the sample of customers based on their residential location is a better measure of the demographics of the store's customers than information based on the store location since stores are typically located in retail-zoned zip-codes or census tract with different demographics than the residential neighborhoods that they draw customers from.

${ }^{23}$ The prices used are the Energy Information Administrations weekly average price of regular unleaded reformulated gasoline in Los Angeles, CA.
} 
also represents a large portion of store revenues. Cereals for this grocery chain are approximately $12 \%$ of weekly revenues. So they represent an economically important category for retail firms and consumers alike. In addition, the prices for boxed cereals are non-trivial, and it is a category with frequent and substantial promotional sales. The mean price for a box of cereal in our sample is $\$ 4.22$, with a standard deviation of $\$ 0.83$. The mean price net promotional discount is $\$ 3.78$ with a standard deviation of $\$ 1.07$. The average promotion is a $34 \%$ discount of the regular price with a standard deviation of $16 \%$. The large average promotional discount is driven by frequent buy one get one free sales. Approximately 32\% of the UPC observations in our data set are on sale.

For the dependent variable we construct the log of the fraction of sales in each week in each store that are from sale (or price discounted) items. ${ }^{24}$ We adjust the prices of cereals to account for differences in box sizes, standardizing the prices so that they are comparable across boxes. Table VIII presents regression results for the effect of the log of gasoline prices on the log of the fraction of cereal that is purchased on promotion. Each regression includes a full set of controls: store level fixed effects, regional time trends, regional monthly dummies, and holiday fixed effects. Holiday effects include separate dummies by year for major holidays and the week before and after the holiday if it falls on a weekend (Thanksgiving, Christmas, New Years, and Fourth of July). We also control for the fraction of UPCs that are on sale within a given week and its square. We allow for first-order autocorrelation in the error terms. ${ }^{25}$

The first column in Table VIII presents the coefficients of interest for all stores in the sample. Gasoline prices enter positively and significantly with a coefficient of 0.19 . On average, if gasoline prices rise by $100 \%$, the fraction of within-store cereal purchases that come from promotional items rises by $19 \%$. The mean of the fraction of items on sale is listed in the table as well. This percent increase is relative to a mean of $65 \%$, hence it represents a 12 percentage point increase in the fraction of cereal that is bought on

\footnotetext{
${ }^{24}$ We use all cereals in this category, but drop cereals that appear very infrequently (for example holiday or themed versions of cereals that only appear for a short duration).

${ }^{25}$ Since we have a very long time series, the bias introduced from autocorrelation in the fixed-effects model is negligible (Hsiao, 1986).
} 
promotion. This is more than a one standard-deviation increase in the fraction of items sold on sale.

Columns 2 through 5 present regression results separately for quartiles of the income distribution. Column two presents results for stores with a median customer income of less than $\$ 50,000$. Columns 3,4 and 5 present results for stores where the median customer income is between $\$ 50,000$ and $\$ 69,500$, between $\$ 69,500$ and $\$ 90,500$, and greater than $\$ 90,500$ respectively. ${ }^{26}$ The coefficient on gasoline prices is strongest for the lowest income category and generally decreases as we move from 2 to column 5. A 100\% increase in gasoline prices translates into a $27 \%, 17 \% 18 \%$ and $15 \%$ increase in the fraction of cereal sold on promotion respectively across the four income categories.

Figure II plots a smoothed nearest-neighbor regression line for the residuals from the regression in Table VIII Column 3 excluding gasoline prices, and the residuals from a regression of gasoline prices on the other right-hand-side variables from the regression in Table VIII (excluding gasoline prices) for four different stores. The four stores were selected from our sample using a random number generator. These residual regression lines represent the variation in the percent of cereal purchases from promotional items and the variation in gasoline prices after controlling for regional trends, monthly effects, holidays, store fixed effects, and the fraction of UPCs on sale at that store during that week and its square. The figures graphically illustrate the relationship between gasoline prices and the percent of purchases coming from promotions after other factors have been appropriately controlled for. They show a positive relationship between the percent of cereal purchases coming from items on sale and gasoline prices, although it appears that the response in the residual for cereal purchases follows the gasoline price residuals with a slight lag, indicating that consumers may adjust their purchases as they realize changes in account balances through the month.

\footnotetext{
${ }^{26}$ These categories were determined by the quartiles of the distribution of median customer-level income across stores in our sample.
} 
Table IX presents regression results with the quantity-weighted net price paid for cereals sold over our time period. The regression specification is identical to that of Table VIII, with "the log of quantity-weighted net prices" instead of the "log of percent of items sold on promotion" as the dependent variable. The results show that the quantity weighted net price falls significantly when gasoline prices increase. If gasoline prices increase by 100 percent, the quantity weighted price paid by consumers falls on average by 5 percent. The average quantity weighted price is approximately $\$ 3$ and this implies that the quantityweighted net price paid falls by about 15 cents. Interestingly, comparing the low with the high income category estimated effects, the high income type has smaller responses to gasoline prices in percent of products purchased on promotion and also has a smaller decrease in standardized net prices compared to the lowest income category.

An average savings of 5 percent on the price of cereal paid in response to a doubling in gasoline prices represents a sizable, but not unreasonable income effect. Using the statistics in Table I on category expenditures form California CES respondents, a 100\% increase in gasoline prices would lead to a 3.74\% decrease in income for non-gasoline consumption. Using our estimates from Table III, this $100 \%$ increase in gasoline prices results in a $-0.56 * 6.86 \%=-3.84 \%$ decrease in food-away-from home expenditure and a $0.15 * 11.77=1.76$ increase in food-at-home expenditure. If consumers substitute towards sale items across all grocery categories in a similar manner, they would save $0.05 * 11.77=-0.59 \%$ of income spent on groceries simply by substituting towards promotional items.

We may be concerned that grocery prices change in a strategic way when gasoline prices increase due to an expected demand response. We do know that the grocery retailer that we are working with does not adjust retail prices with gasoline prices, and we also know that shelf prices are very sticky, not changing as frequently as gasoline prices have over this period (Bils and Klenow; 2004, Eichenbaum, Jaimovich, and Rebelo, 2007; Kehoe and Midrigan, 2007; and Nakamura and Steinsson, 2007). However, we create a price index to examine if prices consumers faced change with gasoline prices. The index weights each cereal by a time-constant share of sales over the time period at each store so 
that it varies with price level but not with quantity purchased over time. ${ }^{27}$ We create two indexes; one that uses shelf-prices and one that uses prices net of promotional discounts (net-prices are equal to shelf-prices if there is no discount). Table $\mathrm{X}$ shows the effect of gasoline prices on each of the price indexes, controlling for store-level fixed-effects and regional time trends. The first column shows that gasoline prices have no effect on shelfprices, as expected. However, the second column shows a positive and significant impact of gasoline prices on net prices. The point estimate implies a 5 percent increase in net prices as a result of a 100 percent increase in gasoline prices, which is similar to other estimates of cost-based increase in PPI and CPI resulting from fuel price increases (see e.g., Chinkook, 2002; Reed et. al, 1997; Urbanchuk, 2007). Hence product prices appear to adjust flexibly with gasoline prices through the size of discounts and promotions, which change weekly even though shelf-prices remain stable over long time periods.

Note that an increase in net-prices when gasoline prices increase will work against our findings, since increases in net-prices (with no impact on gross-prices) should make promotional items relatively less attractive to consumers and lower their ability to decrease category expenditures by purchasing promotional items. We can control directly for changes in net-price index in our regression analysis. Table XI presents the specification in Table IX, but also controls for the log of the net-price index as well. The effect of gasoline prices is now slightly larger, implying that a 100 percent increase in gasoline prices leads to a $6.4 \%$ decrease in net-price paid. ${ }^{28}$

\footnotetext{
${ }^{27}$ We create this index only for the brands of cereal which are always sold in every store over our period. This approach is similar to the approach others have taken in the literature (Chevalier et al., 2003; Hoch et al., 1995). This index is correlated with price changes due to changes in input costs but does not change due to changes over time in which products we observe being sold. The products we observe being sold change when new products enter, when products exit, or when infrequently-purchased items are sold. These changes the products purchased are part of the variation we want to include when measuring fraction of products sold on sale and quantity-weighted price paid, but not when measuring changes in prices due to input costs, for example.

${ }^{28}$ One thing we cannot examine is if gasoline prices affect the relative prices of all grocery products differently, since we only have access to a handful of product categories. For example, in Connecticut, where apples are grown locally, it may be the case that gasoline prices cause larger increases in net prices for oranges than for apples, causing low-income and more price sensitive consumers to substitute away from oranges towards apples, and thus increasing the fraction of items purchased on sale and the net price paid for apples independently of a direct income effect from gasoline. We do examine four product categories that a priori may not have such easy substitutes and find similar overall effects as we do in the cereal category. We are currently working on incorporating income effects into a model of grocery-product choice.
} 
Tables XII through XIV present similar regressions to those presented in Table IX for three additional product categories: Family Yogurt, Fresh Chicken, and Refrigerated Orange Juice (hereafter yogurt, chicken and orange juice respectively). ${ }^{29}$ Each table contains two panels of regressions, one showing the effect of log of gasoline prices on the log of percent of products sold on promotion and the other showing the effect on the log of quantity-weighted prices.

Table XII presents results for yogurt. ${ }^{30}$ This category has frequent promotions with 30\% of the UPC observations in our sample on sale. The average gross price is $\$ 0.81$ for a sixounce serving, with a standard deviation of $\$ 0.22$, while the average net price is $\$ 0.73$ with a standard deviation of $\$ 0.24$. The average promotional discount is a $34 \%$ discount off the regular price with a standard deviation of $12 \%$. Typically all flavors of a particular brand go on sale at the same time. The top panel of regressions in Table XII shows that as gasoline prices increase by 100 percent, the percent of yogurt sold that is on promotion increases by $25 \%$. Again, the largest effect is for stores located in low-income neighborhoods. The second set of regressions in the bottom panel show that the quantity weighted price paid for yogurt falls as gasoline prices increase. The quantity weighted price paid falls by approximately 5.2 cents per cup of yogurt if gasoline prices rises by 100 percent. The effect on net price paid is not significantly different across the different income categories.

Table XIII presents results for fresh chicken. In this category, the main product differentiation is by cut of meat; boneless-skinless, breast, leg, thigh, drumsticks, etc. There are not many brand varieties, and organic or free-range varieties were not prevalent at this retail chain during this time period. Price is measured in price per pound, and quantity sold is measured in pounds. For fresh chicken, 32\% of the observations in the data set are on promotion. The average gross price per pound across products is $\$ 3.37$

\footnotetext{
${ }^{29}$ In each category, we account for different container sizes when calculating prices. For example, yogurt is in price per six ounce serving and chicken is in price per pound.

${ }^{30}$ For the yogurt category, we considered only cup yogurt and excluded large yogurt tubs used primarily for cooking.
} 
with a standard deviation of $\$ 1.76$, and the average net price per pound is $\$ 3.10$ with a standard deviation of $\$ 1.75$. The average markdown is $27 \%$ of the price with a standard deviation of $15 \%$. Hence the average markdown as a percent of price is lowest for this category. The fist set of regressions in the top panel of Table XIII show that a $100 \%$ increase in the price of gasoline is associated with a $49 \%$ increase in the fraction of fresh chicken purchased on promotion on average. The effect of gasoline prices on the percent sold on promotion does vary across the store-location income categories as it did for the previous two products. Interestingly the increase in promotional purchases translates into decreases in prices paid more for stores located in middle-income neighborhoods than for stores in the lowest-income neighborhood. This implies that consumers at stores in income groups 2-4 purchase items with higher average markdowns when they substitute towards items on sale.

Table XIV presents results for the fresh orange juice category. The regression results in the top panel indicate that a $100 \%$ increase in the price of gasoline is associated with a $10 \%$ increase in the fraction of orange juice purchased on promotion. The effect of gasoline prices on the percent sold on promotion however, is smallest for the lowest income category and similar for the other three income categories. This may be due to differences in the relative wealth of those who purchase fresh orange juice (instead of frozen or shelf-stable sweetened drinks) or the relative substitutability of fresh orange juice for other drinks in stores serving consumers with lower median income levels versus stores serving customers with higher median income. In addition, the decrease in quantity weighted price paid is significant, but statistically the same across all income categories.

Finally, Table XV considers the effect of gasoline prices on overall net revenues for the retailer. The analysis of the CES data implied that grocery expenditures rise when gasoline prices rise, as consumers substitute away from food purchased away-from-home towards less expensive grocery products. We will not be able to look at total volume sold and total store revenues for all grocery food products, but we can look at how these two statistics change for the four categories in our analysis. The top panel shows the effect of 
gasoline prices on total quantity sold in each of our categories, and the bottom panel shows the effect on total revenues. We include the same regression controls as those in Tables VIII-XIV. Across all four categories, total quantity sold increases significantly with gasoline prices. It is important to note that this increase in quantity sold includes both potential increases in volume sold due to substitution away from eating-out towards groceries as well as substitution within groceries between categories (e.g. from beef to chicken). The second panel shows increases in revenues, which takes into account both increases in sales when gasoline prices rise as well as decreases in average price paid as consumers substitute towards items on promotion. The increases in revenues for cereal and orange juice are similar to the estimates for increases in grocery expenditures in the CES data: the estimates imply that expenditures increase by $30 \%$ and $12 \%$ for those two categories respectively when gasoline prices increase by $100 \%$. The estimates for chicken and yogurt are substantially higher. This may be because across all groceries, these two items are easy substitutes for lunches and snacks (yogurt) or dinner (chicken). In addition, chicken sales and revenues may increase more as people substitute within store away from more expensive beef and towards the cheaper chicken.

\section{Conclusion}

This paper uses data from the detailed diary files of the Consumer Expenditure Survey and detailed scanner data to examine if grocery and food expenditures change with small shocks to disposable income. We use spikes in gasoline prices to examine how changes in disposable income affect stated food expenditures in the CES and actual scanner-data grocery purchases at the grocery store. We find several interesting results. First, we show that gasoline expenditures as reported in the CES increase one for one with gasoline prices. While consumers cannot easily substitute away from gasoline when prices rise, we find using the CES diary files that they decrease expenditures on food-away-from-home and substitute towards purchasing food at grocery stores. We then show that consumers substitute further within their grocery store purchases. Using survey data and scanner data for four frequently purchased food categories, we find that consumers substitute towards items that are on sale and away from full-price items when gasoline prices spike. 
This significantly reduces their overall price paid per unit purchased by an average of 5$11 \%$ in the categories we study.

These findings have a variety of implications for modeling in micro and macroeconomics. Given that we find significant effects of gasoline prices on grocery purchases, price sensitivity, and product choice, discrete choice models used to estimate consumer choice and competition between products (e.g., McFadden, 1974; Berry 1994; and Berry, Levinsohn and Pakes, 1995) might be adapted to incorporate income effects (de Palma and Kilani, 1999 or Allenby and Rossi, 1991). A second implication relates to the important role of product substitution and consumption smoothing analysis in the presence of income shocks. First we find evidence that consumption patterns respond to changes in disposable income due to spikes in gasoline prices. However, we find that consumers display both across-category substitution (food-away-from-home versus groceries) and within-category substitution towards products on promotion. Hence actual consumption might not change as much in response to small income shocks as overall expenditures do. Aguiar and Hurst (2005, 2007a and 2007b) provide evidence of the importance of substitution to explain consumption and expenditure effects at the time of retirement. We find that consumers smooth consumption across categories, reducing expenditures by substituting towards lower-cost food at the grocery store, and lower priced items within grocery category in order to curb expenditures when gasoline prices rise. 


\section{REFERENCES}

Aguiar, M. and E. Hurst, 2005. "Consumption versus Expenditure,” Journal of Political Economy, 113, N. 5, 919-948.

Aguiar, M. and E. Hurst, 2007a. "Measuring Leisure: The Allocation of Time over Five Decades,” forthcoming Quarterly Journal of Economics, August 2007, 122, N. 3.

Aguiar, M. and E. Hurst, 2007b. "Lifecycle Prices and Production," forthcoming American Economic Review.

Allenby, G. and P. Rossi, 1991. "Quality Perceptions and Asymmetric Switching between Brands,” Marketing Science, 10 (3) , 185-204.

Bernanke, B. S., 1983. "Irreversibility, Uncertainty, and Cyclical Investment.” Quarterly Journal of Economics. February, 98:1; 85-106.

Barsky, R. B, and L. Killian, 2004. "Oil and the Macroeconomy Since the 1970s," Journal of Economic Perspectives, 18, N. 4, 115-134.

Berry, S., 1994. "Estimating Discrete-Choice Models of Product Differentiation," RAND Journal of Economics, 25, No. 2:242-262.

Berry, S., J.Levinsohn, and A. Pakes, 1995. "Automobile Prices in Market Equilibrium,” Econometrica, 63, No. 4: 841-890.

Bils, M. and P.J. Klenow, 2004. "Some Evidence on the Importance of Sticky Prices," Journal of Political Economy, 112 (5): 947-985.

Blattberg, R. C. and K. Wisniewski, 1989. "Price-Induced Patterns of Competition," Marketing Science, 8, 291-310.

Card, D., R. Chetty, and A. Weber, 2006. "Cash-on-Hand and Competing Models of Intertemporal Behavior: New Evidence from the Labor Market", forthcoming Quarterly Journal of Economics.

Chetty, R. and A. Szeidl, 2007. "Consumption Commitments and Risk Preferences," Quarterly Journal of Economics, 122(2): 831-877.

Chevalier, Judith, A. Kashyap, and P. Rossi, 2003 "Why Don’t Prices Rise During Periods of Peak Demand? Evidence from Scanner Data," American Economic Review, 93(1), 15-37.

Chinkook, L, 2002. "The Impact of Intermediate Input Price Changes on Food Prices: An Analysis of "From the Ground Up” Effects.” Journal of Agribusiness 20 (1). 
Cullen, J. B., L. Friedberg, and C. Wolfram, 2004. “Consumption and Changes in Home Energy Costs: How Prevalent is the Heat or Eat Decision?, working paper, March.

Dahl, C. and T. Sterner, 1991. "Analyzing Gasoline Demand Elasticities: A Survey." Energy Economics 3(13): 203-210.

De Palma and K. Kilani, 1999. “Discrete Choice Models with Income Effects,” working paper, November.

Deaton, A., 1991. "Saving and Liquidity Constraints," Econometrica, Vol. 59, No. 5. (Sep.): 1221-1248.

Eichenbaum, M., N. Jaimovich and S. Rebelo, 2007. "Reference Prices and Nominal Rigidities," mimeo, Northwestern University.

Espey, M., 1998. "Gasoline Demand Revisited: An International Meta-Analysis of Elasticities." Energy Economics 20: 273-295.

Gruber, J., 1997. “The Consumption Smoothing Benefits of Unemployment Insurance,” American Economic Review, Vol. 87, No. 1. (March): 192-205.

Hamilton, J.D., 1983. “Oil and the Macroeconomy since World War II,” The Journal of Political Economy, 91, N. 2; 228-248.

Hamilton, J.D., 1983. “A Neoclassical Model of Unemployment and the Business Cycle,” Journal of Political Economy, 96, June 1988, pp. 593-617.

Heath, C. and J. B. Soll, 1996. "Mental Budgeting and Consumer Decisions," The Journal of Consumer Research, Vol. 23, No. 1. (June); 40-52.

Hoch, Steven J., B.-D. Kim, A. L. Montgomery, and P. E. Rossi, 1995. "Determinants of Store-Level Price Elasticity, " Journal of Marketing Research, 32 (1):17-29.

Hughes, J. E., C. R. Knittel, and D. Sperling, 2006. "Evidence of a Shift in the Short-Run Price Elasticity of Gasoline Demand,” working paper.

Hsiao, C., 1986. “Analysis of Panel Data,” Cambridge University Press: Cambridge, MA.

Kamakura, W. A. and G. J. Russell, 1989. "A Probabilistic Choice Model for Market Segmentation and Elasticity Structure,” Journal of Marketing Research, 26, 379390.

Kehoe, P. J. and V. Midrigan, 2007 "Sales and the Real Effects of Monetary Policy," mimeo, Federal Reserve Bank of Minneapolis. 
Mankiw, N. G., 2000. “The Savers-Spenders Theory of Fiscal Policy,” American Economic Review, Vol. 90, No. 2, Papers and Proceedings of the One Hundred Twelfth Annual Meeting of the American Economic Association. (May); 120125.

McFadden, D., 1974. "Conditional Logit Analysis of Qualitative Choice Behavior," in P. Zarembka (ed.), Frontiers in Econometrics, 105-142, Academic Press: New York.

Nakamura, E. and J. Steinsson. 2007. "Five Facts About Prices: A Re-evaluation of Menu Cost Models," mimeo, Harvard University.

Nicol, C. J., 2003. "Elasticities of Demand for Gasoline in Canada and the United States." Energy Economics 25(2): 201-214.

Parker, J., 1999. "The Reaction of Household Consumption to Predictable Changes in Social Security Taxes.” American Economic Review 89 (4): 959-73.

Poterba, J. M., 1988. “Are Consumers Forward Looking? Evidence from Fiscal Experiments,” American Economic Review, Vol. 78, No. 2, Papers and Proceedings of the One-Hundredth Annual Meeting of the American Economic Association. (May): 413-418.

Puller, S. L. and L. A. Greening, 1999. "Household Adjustment to Gasoline Price Change: An Analysis Using 9 Years of Us Survey Data." Energy Economics 21(1): 37-52.

Read, D., G. Loewenstein, and M. Rabin, 1999. “Choice Bracketing,” Journal of Risk and Uncertainty, 19:1-3; 171-197.

Reed, A. J., K. Hanson, H. Elitzak, and G. Schluter, 1997. “Changing Consumer Food Prices: A User’s Guide to ERS Analyses”. USDA Economic Research Service. Technical Bulletin 1862. June.

Rotemberg, J. J., and M. Woodford, 1996. "Imperfect Competition and the Effects of Energy Price Increases,” Journal of Money, Credit, and Banking, 28 (part 1): 549577.

Shapiro, J., 2005. "Is there a Daily Discount Rate? Evidence from the Food Stamp Nutrition Cycle.” Journal of Public Economics 89(2-3): 303-325, February.

Shapiro, M. D., and J. Slemrod, 1995. "Consumer Response to the Timing of Income: Evidence from a Change in Tax Withholding," American Economic Review, (March), 274-283.

Shea, J., 1995. "Union Contracts and the Life-Cycle/Permanent-Income Hypothesis,” The American Economic Review, 85 (1):186-200. 
Souleles, N., 1999. "The Response of Household Consumption to Income Tax Refunds.” American Economic Review 89 (4): 947-958.

Stephens, M., 2003. “’3rd of tha Month’: Do Social Security Recipients Smooth Consumption Between Checks?” American Economic Review 93 (1): 406-422.

Thaler, R.H., 1985. “Mental Accounting and Consumer Choice,” Marketing Science, 4, 199-214.

Urbanchuk, J. M., 2007. “The Relative Impact of Corn and Energy Prices in the Grocery Aisle,” LECG LLC.

John M. Urbanchuk 
Table I: Average Income and Expenditures by Category, 2002 Consumer Expenditure Survey

\begin{tabular}{|c|c|c|c|c|c|c|}
\hline & $\begin{array}{c}\text { All } \\
\text { Respondents } \\
\end{array}$ & $\begin{array}{c}5^{\text {th }} \\
\text { Income } \\
\text { Quintile } \\
\end{array}$ & $\begin{array}{c}4^{\text {th }} \\
\text { Income } \\
\text { Quintile } \\
\end{array}$ & $\begin{array}{c}3^{\text {rd }} \\
\text { Income } \\
\text { Quintile } \\
\end{array}$ & $\begin{array}{c}2^{\text {nd }} \\
\text { Income } \\
\text { Quintile } \\
\end{array}$ & $\begin{array}{c}1^{\text {st }} \\
\text { Income } \\
\text { Quintile } \\
\end{array}$ \\
\hline \multicolumn{7}{|c|}{ Panel A: West Coast Region, 2002 (average price of regular gasoline: \$1.373) } \\
\hline Total Food & $16.75 \%$ & $8.59 \%$ & $10.94 \%$ & $14.49 \%$ & $19.99 \%$ & $34.3 \%$ \\
\hline Food Away from Home & $5.75 \%$ & $3.62 \%$ & $4.12 \%$ & $4.97 \%$ & $6.10 \%$ & $11.22 \%$ \\
\hline Food at Home & $11.00 \%$ & $4.96 \%$ & $6.81 \%$ & $9.52 \%$ & $13.89 \%$ & $23.08 \%$ \\
\hline Cereals & $0.32 \%$ & $0.14 \%$ & $0.17 \%$ & $0.27 \%$ & $0.43 \%$ & $0.69 \%$ \\
\hline Dairy & $1.30 \%$ & $0.58 \%$ & $0.77 \%$ & $1.07 \%$ & $1.56 \%$ & $2.96 \%$ \\
\hline Poultry & $0.38 \%$ & $0.17 \%$ & $0.23 \%$ & $0.29 \%$ & $0.47 \%$ & $0.83 \%$ \\
\hline Other Meat & $1.63 \%$ & $0.72 \%$ & $1.01 \%$ & $1.34 \%$ & $2.26 \%$ & $3.29 \%$ \\
\hline Non-alcoholic beverages & $0.98 \%$ & $0.46 \%$ & $0.57 \%$ & $0.79 \%$ & $1.13 \%$ & $2.28 \%$ \\
\hline Clothing & $4.45 \%$ & $2.74 \%$ & $2.99 \%$ & $3.42 \%$ & $4.55 \%$ & $9.67 \%$ \\
\hline Leisure and Entertainment & $1.21 \%$ & $0.92 \%$ & $0.80 \%$ & $1.10 \%$ & $0.97 \%$ & $2.50 \%$ \\
\hline Mortgage or Rent & $24.84 \%$ & $17.19 \%$ & $16.07 \%$ & $19.96 \%$ & $26.39 \%$ & $50.06 \%$ \\
\hline Gasoline and Motor Oil & $3.37 \%$ & $1.69 \%$ & $2.43 \%$ & $3.12 \%$ & $4.21 \%$ & $6.21 \%$ \\
\hline Income after taxes & $\$ 51,143$ & $\$ 111,786$ & $\$ 57,649$ & $\$ 35,198$ & $\$ 21,558$ & $\$ 9,431$ \\
\hline Number of Surveys & 1,422 & 338 & 293 & 291 & 255 & 245 \\
\hline \multicolumn{7}{|c|}{ Panel B: California, 2002 (average price of regular gasoline: \$1.514) } \\
\hline Total Food & $18.63 \%$ & $8.79 \%$ & $12.19 \%$ & $15.07 \%$ & $21.98 \%$ & $40.95 \%$ \\
\hline Food Away from Home & $6.86 \%$ & $4.02 \%$ & $5.55 \%$ & $5.27 \%$ & $6.65 \%$ & $14.39 \%$ \\
\hline Food at Home & $11.77 \%$ & $4.77 \%$ & $6.65 \%$ & $9.80 \%$ & $15.32 \%$ & $26.56 \%$ \\
\hline Cereals & $0.32 \%$ & $0.12 \%$ & $0.15 \%$ & $0.28 \%$ & $0.49 \%$ & $0.70 \%$ \\
\hline Dairy & $1.37 \%$ & $0.56 \%$ & $0.74 \%$ & $1.07 \%$ & $1.49 \%$ & $3.46 \%$ \\
\hline Poultry & $0.42 \%$ & $0.16 \%$ & $0.23 \%$ & $0.34 \%$ & $0.57 \%$ & $0.98 \%$ \\
\hline Other Meat & $1.75 \%$ & $0.74 \%$ & $0.98 \%$ & $1.40 \%$ & $2.56 \%$ & $3.76 \%$ \\
\hline Non-alcoholic beverages & $1.06 \%$ & $0.44 \%$ & $0.55 \%$ & $0.80 \%$ & $1.43 \%$ & $2.48 \%$ \\
\hline Clothing & $5.16 \%$ & $2.76 \%$ & $4.08 \%$ & $3.74 \%$ & $3.78 \%$ & $12.64 \%$ \\
\hline Leisure and Entertainment & $5.16 \%$ & $0.87 \%$ & $0.77 \%$ & $0.95 \%$ & $0.64 \%$ & $2.09 \%$ \\
\hline Mortgage or Rent & $26.58 \%$ & $20.08 \%$ & $18.40 \%$ & $18.91 \%$ & $32.77 \%$ & $47.96 \%$ \\
\hline Gasoline and Motor Oil & $3.74 \%$ & $1.80 \%$ & $2.86 \%$ & $3.43 \%$ & $4.85 \%$ & $6.90 \%$ \\
\hline Income after taxes & $\$ 56,327$ & $\$ 122,397$ & $\$ 58,335$ & $\$ 35,146$ & $\$ 21,776$ & $\$ 9,751$ \\
\hline Number of Surveys & 506 & 137 & 93 & 105 & 79 & 92 \\
\hline
\end{tabular}

Source: Detailed Diary Survey Files from the 2002 Consumer Expenditure Survey. 
Table II: Regression of Gasoline Prices on Gasoline Expenditures

\begin{tabular}{|c|c|c|}
\hline $\begin{array}{l}\text { Dependent Variable: } \\
\text { In(Total Weekly Gasoline Expenditures) }\end{array}$ & $\begin{array}{c}\text { (1) } \\
\text { All Households }\end{array}$ & $\begin{array}{c}\text { (2) } \\
\text { Urban Households } \\
\end{array}$ \\
\hline In(Gasoline Price) & $\begin{array}{l}1.027 * * * \\
(0.097)\end{array}$ & $\begin{array}{c}1.045^{* * *} \\
(0.099)\end{array}$ \\
\hline Number of Vehicles & $\begin{array}{c}0.109 * * * \\
(0.009)\end{array}$ & $\begin{array}{c}0.110^{* * *} \\
(0.010)\end{array}$ \\
\hline Number of Vehicles Squared & $\begin{array}{l}-0.002^{* * *} \\
(0.000)\end{array}$ & $\begin{array}{l}-0.002 * * * \\
(0.000)\end{array}$ \\
\hline After-Tax Income (in thousands \$) & $\begin{array}{c}0.003^{* * *} \\
(0.001)\end{array}$ & $\begin{array}{c}0.003^{* * *} \\
(0.001)\end{array}$ \\
\hline After-Tax Income Squared & $\begin{array}{c}-0.0000^{* *} \\
(0.000)\end{array}$ & $\begin{array}{l}-0.0000^{* *} \\
(0.000)\end{array}$ \\
\hline Age & $\begin{array}{c}0.015^{* * *} \\
(0.002)\end{array}$ & $\begin{array}{c}0.016^{* * *} \\
(0.003)\end{array}$ \\
\hline Age Squared & $\begin{array}{c}0.000 * * * \\
(0.000)\end{array}$ & $\begin{array}{c}0.000 * * * \\
(0.000)\end{array}$ \\
\hline Family Size & $\begin{array}{c}0.101^{* * *} \\
(0.016)\end{array}$ & $\begin{array}{c}0.103^{* * *} \\
(0.016)\end{array}$ \\
\hline Family Size Squared & $\begin{array}{c}-0.006^{* * *} \\
(0.002)\end{array}$ & $\begin{array}{c}-0.006^{* * *} \\
(0.002)\end{array}$ \\
\hline Female & $\begin{array}{c}-0.067 * * * \\
(0.014)\end{array}$ & $\begin{array}{c}-0.070 * * * \\
(0.015)\end{array}$ \\
\hline Employed & $\begin{array}{c}0.023 \\
(0.015)\end{array}$ & $\begin{array}{c}0.016 \\
(0.016)\end{array}$ \\
\hline Whether Children Present & $\begin{array}{l}-0.012 \\
(0.023)\end{array}$ & $\begin{array}{l}-0.025 \\
(0.024)\end{array}$ \\
\hline Population Size of PSU ${ }^{\mathrm{a}}$ & $\begin{array}{l}-0.009 \\
(0.005)\end{array}$ & $\begin{array}{l}-0.023 * * * \\
(0.006)\end{array}$ \\
\hline Whether on Welfare & $\begin{array}{l}-0.097 \\
(0.055)\end{array}$ & $\begin{array}{l}-0.088 \\
(0.056)\end{array}$ \\
\hline Nonwhite & $\begin{array}{c}0.027 \\
(0.028)\end{array}$ & $\begin{array}{c}0.021 \\
(0.028)\end{array}$ \\
\hline College & $\begin{array}{l}-0.015 \\
(0.015)\end{array}$ & $\begin{array}{l}-0.010 \\
(0.015)\end{array}$ \\
\hline Income Quartile Dummies & $\mathrm{Y}$ & $\mathrm{Y}$ \\
\hline Monthly Dummies & $\mathrm{Y}$ & $\mathrm{Y}$ \\
\hline Yearly Dummies & $\mathrm{Y}$ & $\mathrm{Y}$ \\
\hline Time Trend & $\mathrm{Y}$ & $\mathrm{Y}$ \\
\hline $\begin{array}{l}\mathbf{N} \\
\text { R Squared }\end{array}$ & $\begin{array}{c}10,354 \\
0.147\end{array}$ & $\begin{array}{l}9,760 \\
0.155\end{array}$ \\
\hline
\end{tabular}

Note: Standard errors are in parentheses. Asterisks indicate significance $\left(*=.05, * *=.01,{ }^{* * *}=.001\right)$.

${ }^{a}$ PSU are initials for Primary Sampling Unit in the Consumer Expenditure Survey. 
Table III: Regression of Food Expenditures on Gasoline Prices

\begin{tabular}{|c|c|c|c|c|}
\hline \multirow[t]{2}{*}{ Dependent Variable: } & \multicolumn{2}{|c|}{ In(Food Away from Home) } & \multicolumn{2}{|c|}{$\ln ($ Food from Grocery Store) } \\
\hline & $\begin{array}{c}\text { All } \\
\text { Households }\end{array}$ & $\begin{array}{c}\text { Urban } \\
\text { Households }\end{array}$ & $\begin{array}{c}\text { All } \\
\text { Households }\end{array}$ & $\begin{array}{c}\text { Urban } \\
\text { Households }\end{array}$ \\
\hline In(Gasoline Price) & $\begin{array}{c}-0.562 * * \\
(0.175)\end{array}$ & $\begin{array}{c}-0.449 * \\
(0.176)\end{array}$ & $\begin{array}{c}0.146 \\
(0.090)\end{array}$ & $\begin{array}{c}0.189 * \\
(0.089)\end{array}$ \\
\hline Number of Vehicles & $\begin{array}{c}0.119 * * * \\
(0.018)\end{array}$ & $\begin{array}{c}0.117 * * * \\
(0.019)\end{array}$ & $\begin{array}{c}0.039 * * * \\
(0.007)\end{array}$ & $\begin{array}{c}0.038^{* * *} \\
(0.008)\end{array}$ \\
\hline Num. of Vehicles Squared & $\begin{array}{c}-0.006 * * * \\
(0.001)\end{array}$ & $\begin{array}{c}-0.006 * * * \\
(0.001)\end{array}$ & $\begin{array}{l}0.000 * * \\
(0.000)\end{array}$ & $\begin{array}{c}0.000 * * \\
(0.000)\end{array}$ \\
\hline $\begin{array}{l}\text { After-Tax Income } \\
\quad \text { (in thousands of \$) }\end{array}$ & $\begin{array}{c}0.005^{* * * *} \\
(0.001)\end{array}$ & $\begin{array}{c}0.005^{* * *} \\
(0.001)\end{array}$ & $\begin{array}{l}0.002^{* * *} \\
0.001\end{array}$ & $\begin{array}{c}0.003^{* * *} \\
(0.001)\end{array}$ \\
\hline After-Tax Income Squared & $\begin{array}{c}-0.0000^{*} \\
(0.000)\end{array}$ & $\begin{array}{c}-0.0000^{*} \\
(0.000)\end{array}$ & $\begin{array}{c}-0.0000 * * \\
(0.000)\end{array}$ & $\begin{array}{c}-0.0000^{* *} \\
(0.000)\end{array}$ \\
\hline Age & $\begin{array}{c}0.015^{* *} \\
(0.005)\end{array}$ & $\begin{array}{c}0.013^{* *} \\
(0.005)\end{array}$ & $\begin{array}{c}0.027^{* * * *} \\
(0.002)\end{array}$ & $\begin{array}{c}0.027^{* * *} \\
(0.003)\end{array}$ \\
\hline Age Squared & $\begin{array}{c}0.000 * * * \\
(0.000)\end{array}$ & $\begin{array}{c}0.000 * * * \\
(0.000)\end{array}$ & $\begin{array}{c}0.000 * * * \\
(0.000)\end{array}$ & $\begin{array}{c}0.000 * * * \\
(0.000)\end{array}$ \\
\hline Family Size & $\begin{array}{c}0.201 * * * \\
(0.029)\end{array}$ & $\begin{array}{c}0.191 * * * \\
(0.030)\end{array}$ & $\begin{array}{c}0.387 * * * \\
(0.018)\end{array}$ & $\begin{array}{c}0.374^{* * *} \\
(0.018)\end{array}$ \\
\hline Family Size Squared & $\begin{array}{c}-0.017 * * * \\
(0.003)\end{array}$ & $\begin{array}{c}-0.015^{* * *} \\
(0.003)\end{array}$ & $\begin{array}{c}-0.026^{* * *} \\
(0.002)\end{array}$ & $\begin{array}{c}-0.025 * * * \\
(0.002)\end{array}$ \\
\hline Female & $\begin{array}{c}-0.056^{*} \\
(0.025)\end{array}$ & $\begin{array}{c}-0.060^{*} \\
(0.026)\end{array}$ & $\begin{array}{l}-0.005 \\
(0.013)\end{array}$ & $\begin{array}{l}-0.006 \\
(0.013)\end{array}$ \\
\hline Employed & $\begin{array}{c}0.000 \\
(0.027)\end{array}$ & $\begin{array}{c}0.004 \\
(0.029)\end{array}$ & $\begin{array}{c}-0.055^{* * *} \\
(0.014)\end{array}$ & $\begin{array}{c}-0.055^{* * * *} \\
(0.014)\end{array}$ \\
\hline Whether Children Present & $\begin{array}{c}-0.143^{* * *} \\
(0.040)\end{array}$ & $\begin{array}{c}-0.143^{* * *} \\
(0.042)\end{array}$ & $\begin{array}{l}-0.030 \\
(0.020)\end{array}$ & $\begin{array}{l}-0.021 \\
(0.020)\end{array}$ \\
\hline Population Size of PSU ${ }^{a}$ & $\begin{array}{c}-0.085^{* * *} \\
(0.009)\end{array}$ & $\begin{array}{c}-0.088 * * * \\
(0.010)\end{array}$ & $\begin{array}{c}-0.029 * * * \\
(0.005)\end{array}$ & $\begin{array}{c}-0.031^{* * *} \\
(0.005)\end{array}$ \\
\hline Whether on Welfare & $\begin{array}{l}-0.116 \\
(0.080)\end{array}$ & $\begin{array}{l}-0.088 \\
(0.080)\end{array}$ & $\begin{array}{l}-0.091^{*} \\
(0.042)\end{array}$ & $\begin{array}{l}-0.104^{*} \\
(0.042)\end{array}$ \\
\hline Nonwhite & $\begin{array}{c}0.025 \\
(0.052)\end{array}$ & $\begin{array}{c}0.012 \\
(0.052)\end{array}$ & $\begin{array}{l}-0.057^{*} \\
(0.030)\end{array}$ & $\begin{array}{l}-0.063^{*} \\
(0.028)\end{array}$ \\
\hline College & $\begin{array}{c}0.104 * * * \\
(0.027)\end{array}$ & $\begin{array}{c}0.105^{* * * *} \\
(0.027)\end{array}$ & $\begin{array}{c}0.037 * * \\
(0.014)\end{array}$ & $\begin{array}{l}0.031^{*} \\
(0.014)\end{array}$ \\
\hline Income Quartile Dummies & $\mathrm{Y}$ & $\mathrm{Y}$ & $\mathrm{Y}$ & $\mathrm{Y}$ \\
\hline Monthly Dummies & $\mathrm{Y}$ & $\mathrm{Y}$ & $\mathrm{Y}$ & $\mathrm{Y}$ \\
\hline Yearly Dummies & $\mathrm{Y}$ & $\mathrm{Y}$ & $\mathrm{Y}$ & $\mathrm{Y}$ \\
\hline Time Trend & $\mathrm{Y}$ & $\mathrm{Y}$ & $\mathrm{Y}$ & $\mathrm{Y}$ \\
\hline $\begin{array}{l}\mathbf{N} \\
\mathbf{R} \text { Squared }\end{array}$ & $\begin{array}{l}8,612 \\
0.126\end{array}$ & $\begin{array}{l}8,152 \\
0.126\end{array}$ & $\begin{array}{l}9,392 \\
0.332\end{array}$ & $\begin{array}{l}8,863 \\
0.336\end{array}$ \\
\hline
\end{tabular}

Note: Standard errors are in parentheses. Asterisks indicate significance $(*=.05, * *=.01, * * *=.001)$.

${ }^{a}$ PSU are initials for Primary Sampling Unit in the Consumer Expenditure Survey. 
Table IV: Summary Statistics for Survey Responses

\begin{tabular}{|c|c|c|c|c|c|}
\hline Variable & N Responses & Mean & St.Dev. & Min & Max \\
\hline \multicolumn{6}{|l|}{ Store 1: Low Income } \\
\hline Income (in thousands) & 324 & 52.92 & 37.02 & 2.5 & 130 \\
\hline Female & 344 & 0.63 & 0.48 & 0 & 1 \\
\hline Number of Commuting Adults & 345 & 1.65 & 1.21 & 0 & 12 \\
\hline Number of Children & 343 & 0.68 & 1.12 & 0 & 7 \\
\hline Household Size & 339 & 3.16 & 1.91 & 0 & 18 \\
\hline Completed College & 351 & 0.31 & 0.46 & 0 & 1 \\
\hline Average Commute Time & 328 & 27.33 & 15.00 & 8 & 50 \\
\hline Ave. Monthly Gas Expend. & 342 & 160.41 & 100.37 & 30 & 350 \\
\hline Response to Question 1 & 340 & 4.13 & 2.14 & 1 & 7 \\
\hline \multicolumn{6}{|l|}{ Store 2: Middle Income } \\
\hline Income (in thousands) & 602 & 52.62 & 37.31 & 2.5 & 130 \\
\hline Female & 668 & 0.62 & 0.48 & 0 & 1 \\
\hline Number of Commuting Adults & 657 & 1.89 & 1.17 & 0 & 6 \\
\hline Number of Children & 647 & 0.84 & 1.05 & 0 & 7 \\
\hline Household Size & 631 & 3.52 & 1.77 & 0 & 14 \\
\hline Completed College & 696 & 0.31 & 0.46 & 0 & 1 \\
\hline Average Commute Time & 652 & 29.49 & 15.53 & 8 & 50 \\
\hline Ave. Monthly Gas Expend & 662 & 164.40 & 102.67 & 30 & 350 \\
\hline Response to Question 1 & 656 & 4.07 & 2.05 & 1 & 7 \\
\hline \multicolumn{6}{|l|}{ Store 3: High Income } \\
\hline Income (in thousands) & 122 & 79.45 & 36.52 & 2.5 & 130 \\
\hline Female & 130 & 0.62 & 0.49 & 0 & 1 \\
\hline Number of Commuting Adults & 133 & 1.71 & 1.61 & 0 & 12 \\
\hline Number of Children & 128 & 0.71 & 1.23 & 0 & 10 \\
\hline Household Size & 130 & 3.02 & 1.61 & 1 & 12 \\
\hline Completed College & 136 & 0.57 & 0.50 & 0 & 1 \\
\hline Average Commute Time & 120 & 28.28 & 15.58 & 8 & 50 \\
\hline Ave. Monthly Gas Expend & 129 & 170.50 & 105.55 & 30 & 350 \\
\hline Response to Question 1 & 128 & 3.82 & 2.15 & 1 & 7 \\
\hline
\end{tabular}

Source: Store exit survey conducted Nov 8, 9 and 10, 2006. 
Table V: Analysis of Survey Responses to Question 1

\begin{tabular}{|lcccccc|}
\hline Dependent Variable: Indicator if Agree that Gas Prices Impact Grocery Purchases \\
Variable & $\begin{array}{c}\text { Model 1 } \\
\text { Coefficient }\end{array}$ & Std.Err. & P Value & Coefficient & Model 2 \\
Std.Err. & P Value \\
\hline Constant & $-1.500^{* *}$ & 0.333 & 0.000 & $-1.814^{* *}$ & 0.369 & 0.000 \\
Income & $-0.040^{*}$ & 0.017 & 0.015 & -- & -- & -- \\
Income spline <=50k & -- & -- & -- & 0.023 & 0.035 & 0.509 \\
Income spline > 50k & -- & -- & -- & $-0.114^{*}$ & 0.056 & 0.040 \\
Monthly Gasoline Expend. & 0.058 & 0.060 & 0.328 & 0.061 & 0.060 & 0.305 \\
Household Size & -0.040 & 0.042 & 0.340 & -0.032 & 0.042 & 0.446 \\
Reads Nutrition Labels & $0.099^{* *}$ & 0.035 & 0.005 & $0.096^{* *}$ & 0.035 & 0.007 \\
Price Shops Across Stores & $0.167^{* *}$ & 0.034 & 0.000 & $0.164^{* *}$ & 0.034 & 0.000 \\
Female & 0.185 & 0.144 & 0.199 & 0.181 & 0.145 & 0.210 \\
& & & & & & \\
N = 948 & & & & N $=946$ & & \\
Log Likelihood: -615.00 & & & & Log Likelihood: -612.89 & \\
\hline
\end{tabular}

Notes: * Denotes statistical significance at the $5 \%$ level or higher, ** denotes statistical significance at $1 \%$ level or higher.

Table VI: Survey Responses on How Grocery Expenditures are Adjusted

\begin{tabular}{|lccccc|}
\hline & Mean & $\begin{array}{c}\text { \% Rank } \\
\text { it Highest }\end{array}$ & $\begin{array}{c}\text { \% Rank } \\
\text { it Lowest }\end{array}$ & \% Agree & \% Disagree \\
\hline $\begin{array}{l}\text { Question 2.1: } \\
\quad \text { Buy Sale Items }\end{array}$ & 6.22 & $86 \%$ & $23 \%$ & $88 \%$ & $5 \%$ \\
$\begin{array}{l}\text { Question 2.2: } \\
\quad \text { Buy Store Brand } \\
\begin{array}{l}\text { Question 2.3: } \\
\quad \text { Buy Less Packaged Goods }\end{array}\end{array}$ & 5.17 & $45 \%$ & $30 \%$ & $60 \%$ & $17 \%$ \\
$\begin{array}{l}\text { Question 2.4: } \\
\text { Buy Less Meat }\end{array}$ & 4.84 & $22 \%$ & $64 \%$ & $34 \%$ & $38 \%$ \\
\hline
\end{tabular}

Source: Store exit survey conducted Nov 8, 9 and 10, 2006. 
Table VII: Summary Statistics for Store-Level Customer Demographics

\begin{tabular}{|llrrrr|}
\hline Variable & N & \multicolumn{1}{c}{ Mean } & Std. Dev. & \multicolumn{1}{c|}{ Min } & \multicolumn{1}{c|}{ Max } \\
\hline \hline $\begin{array}{l}\text { Median Household Income } \\
\quad \text { (Estimated 2006) }\end{array}$ & 180 & $\$ 74,078$ & $\$ 30,359$ & $\$ 16,000$ & $\$ 200,000$ \\
$\begin{array}{l}\text { Median Household Income } \\
\quad \text { (Census block group 2000) }\end{array}$ & 180 & $\$ 64,789$ & $\$ 15,324$ & $\$ 30,258$ & $\$ 121,442$ \\
Ave. Household Size & 180 & 2.759 & 0.325 & 2.057 & 3.916 \\
Median Gross Rent & 180 & $\$ 1,072$ & $\$ 205$ & $\$ 653$ & $\$ 1,691$ \\
Median House Value & 180 & $\$ 300,058$ & $\$ 115,387$ & $\$ 122,894$ & $\$ 766,920$ \\
Percent White & 180 & 0.664 & 0.137 & 0.253 & 0.861 \\
Percent Black & 180 & 0.054 & 0.068 & 0.010 & 0.466 \\
Percent Hispanic & 180 & 0.211 & 0.115 & 0.066 & 0.606 \\
Percent Below Poverty & 180 & 0.092 & 0.041 & 0.026 & 0.278 \\
Percent 65 years plus & 180 & 0.117 & 0.037 & 0.055 & 0.423 \\
Commute Time & 180 & 30.135 & 3.682 & 22.475 & 42.565 \\
Vehicles per Household & 180 & 1.847 & 0.199 & 1.148 & 2.253 \\
\hline
\end{tabular}

*Source: Retailer provided information on loyalty card customers' locations and demographic information. Median Household Income for 2006 is calculated by taking the median of the estimated 2006 households' income for card customers at each store. All other demographics were created by merging data from the 2000 Census at the block group level to each customer's block group, and then aggregating to the store level.

Table VIII: Relationship Between $\ln ($ Percent Sold on Sale) for Cereal and $\ln ($ Gasoline Prices)

\begin{tabular}{|lccccc|}
\hline & All & $\begin{array}{c}\text { Income } \\
\text { Group 1 }\end{array}$ & $\begin{array}{c}\text { Income } \\
\text { Group 2 }\end{array}$ & $\begin{array}{c}\text { Income } \\
\text { Group 3 }\end{array}$ & $\begin{array}{c}\text { Income } \\
\text { Group 4 }\end{array}$ \\
\hline Ln(Gasoline price) & $0.190^{* *}$ & $0.269^{* *}$ & $0.170^{* *}$ & $0.179^{* *}$ & $0.154^{* *}$ \\
Num. Items on Sale & $(0.012)$ & $(0.029)$ & $(0.021)$ & $(0.023)$ & $(0.025)$ \\
& $2.915^{* *}$ & $3.109^{* *}$ & $2.757^{* *}$ & $2.692^{* *}$ & $3.083^{* *}$ \\
Num. Items on Sale Squared & $(0.045)$ & $(0.103)$ & $(0.082)$ & $(0.083)$ & $(0.091)$ \\
& $-2.365^{* *}$ & $-2.657^{* *}$ & $-2.134^{* *}$ & $-2.099^{* *}$ & $-2.536^{* *}$ \\
& $(0.063)$ & $(0.142)$ & $(0.114)$ & $(0.119)$ & $(0.132)$ \\
Other Controls: & & & & & \\
Regional time trends & $\mathrm{Y}$ & $\mathrm{Y}$ & $\mathrm{Y}$ & $\mathrm{Y}$ & $\mathrm{Y}$ \\
Regional month effects & $\mathrm{Y}$ & $\mathrm{Y}$ & $\mathrm{Y}$ & $\mathrm{Y}$ & $\mathrm{Y}$ \\
Holidays & $\mathrm{Y}$ & $\mathrm{Y}$ & $\mathrm{Y}$ & $\mathrm{Y}$ & $\mathrm{Y}$ \\
Store fixed effects & $\mathrm{Y}$ & $\mathrm{Y}$ & $\mathrm{Y}$ & $\mathrm{Y}$ & $\mathrm{Y}$ \\
& & $\mathrm{Y}$ & $\mathrm{Y}$ & $\mathrm{Y}$ & $\mathrm{Y}$ \\
Mean Percent Sold on Sale & 0.645 & 0.661 & 0.660 & 0.643 & 0.616 \\
N Stores & 180 & 42 & 48 & 45 & 45 \\
N Obs & 27540 & 6426 & 7344 & 6885 & 6885 \\
\hline
\end{tabular}

Notes: Standard errors are in parentheses, * denotes statistical significance at the $5 \%$ level or higher, ** denotes statistical significance at $1 \%$ level or higher. Residuals allowed to follow a first-order auto-regressive process. Source: Store level scanner data-set. 
Table IX: Relationship Between $\ln ($ Quantity Weighted Price) for Cereal and $\ln ($ Gasoline Prices)

\begin{tabular}{|lccccc|}
\hline & All & $\begin{array}{c}\text { Income } \\
\text { Group 1 }\end{array}$ & $\begin{array}{c}\text { Income } \\
\text { Group 2 }\end{array}$ & $\begin{array}{c}\text { Income } \\
\text { Group 3 }\end{array}$ & $\begin{array}{c}\text { Income } \\
\text { Group 4 }\end{array}$ \\
\hline \hline Ln(Gasoline price) & $-0.049^{* *}$ & $-0.066^{* *}$ & $-0.036^{* *}$ & $-0.058^{* *}$ & $-0.038^{* *}$ \\
Num. Items on Sale & $(0.007)$ & $(0.016)$ & $(0.013)$ & $(0.013)$ & $(0.013)$ \\
& $-0.497^{* *}$ & $-0.403^{* *}$ & $-0.464^{* *}$ & $-0.516^{* *}$ & $-0.578^{* *}$ \\
Num. Items on Sale Squared & $(0.026)$ & $(0.060)$ & $(0.053)$ & $(0.051)$ & $(0.049)$ \\
& $0.321^{* *}$ & $0.186^{*}$ & $0.275^{* *}$ & $0.341^{* *}$ & $0.448^{* *}$ \\
& $(0.037)$ & $(0.083)$ & $(0.073)$ & $(0.073)$ & $(0.071)$ \\
Other Controls: & & & & & \\
Regional time trends & & & & & \\
Regional month effects & $\mathrm{Y}$ & $\mathrm{Y}$ & $\mathrm{Y}$ & $\mathrm{Y}$ & $\mathrm{Y}$ \\
Holidays & $\mathrm{Y}$ & $\mathrm{Y}$ & $\mathrm{Y}$ & $\mathrm{Y}$ & $\mathrm{Y}$ \\
Store fixed effects & $\mathrm{Y}$ & $\mathrm{Y}$ & $\mathrm{Y}$ & $\mathrm{Y}$ & $\mathrm{Y}$ \\
& & & & & \\
Mean Qt. Weighted Price & 3.099 & 3.026 & 3.055 & 3.114 & 3.199 \\
N Stores & 180 & 42 & 48 & 45 & 45 \\
N Obs & 27540 & 6426 & 7344 & 6885 & 6885 \\
\hline
\end{tabular}

Notes: Standard errors are in parentheses, * denotes statistical significance at the $5 \%$ level or higher, ** denotes statistical significance at $1 \%$ level or higher. Residuals allowed to follow a first-order auto-regressive process. Source: Store level scanner data-set. 
Table X: Effect of Gasoline Prices on Price Index of Family Cereal

\begin{tabular}{|lcc|}
\hline Dependent Variable: & Index of Shelf Prices & $\begin{array}{c}\text { Index of Discounted } \\
\text { Prices }\end{array}$ \\
\hline \hline Ln(Gasoline price) & 0.002 & 0.049 \\
Num. Items on Sale & -0.007 & $(0.009)^{* *}$ \\
& 0.221 & -0.82 \\
Num. Items on Sale & $(0.015)^{* *}$ & $(0.026)^{* *}$ \\
Squared & -0.223 & 0.609 \\
& $(0.021)^{* *}$ & $(0.036)^{* *}$ \\
N Obs & & \\
& & \\
Other Controls: & 27,540 & 27,540 \\
Regional time trends & & \\
Regional month effects & & $\mathrm{Y}$ \\
Holidays & $\mathrm{Y}$ & $\mathrm{Y}$ \\
Store fixed effects & $\mathrm{Y}$ & $\mathrm{Y}$ \\
N Stores & $\mathrm{Y}$ & $\mathrm{Y}$ \\
& 180 & 180 \\
\hline
\end{tabular}

Notes: Standard errors are in parentheses, * denotes statistical significance at the $5 \%$ level or higher, ** denotes statistical significance at $1 \%$ level or higher. Residuals allowed to follow a firstorder auto-regressive process. Source: Store level scanner data-set. 
Table XI: Regression Results for Family Cereal Category Controlling for Price Index

\begin{tabular}{|lcc|}
\hline Dependent Variable: & $\begin{array}{c}\text { Ln (Percent Sold } \\
\text { on Sale) }\end{array}$ & $\begin{array}{c}\text { Ln(Quantity-Weighted } \\
\text { Price Paid) }\end{array}$ \\
\hline \hline Ln(Gasoline price) & 0.206 & -0.064 \\
Ln(Net Price Index) & $(0.012)^{* *}$ & $(0.006)^{* *}$ \\
& -0.468 & 0.42 \\
Num. Items on Sale & $(0.010)^{* *}$ & $(0.005)^{* *}$ \\
& 2.527 & -0.172 \\
Num. Items on Sale Squared & $(0.043)^{* *}$ & $(0.024)^{* *}$ \\
& -2.06 & 0.059 \\
N Obs & $(0.060)^{* *}$ & -0.033 \\
& & \\
Other Controls: & 27,540 & 27,540 \\
Regional time trends & & \\
Regional month effects & $\mathrm{Y}$ & $\mathrm{Y}$ \\
Holidays & $\mathrm{Y}$ & $\mathrm{Y}$ \\
Store fixed effects & $\mathrm{Y}$ & $\mathrm{Y}$ \\
N Stores & $\mathrm{Y}$ & $\mathrm{Y}$ \\
& 180 & 180 \\
\hline
\end{tabular}

Notes: Standard errors are in parentheses, * denotes statistical significance at the $5 \%$ level or higher, ** denotes statistical significance at $1 \%$ level or higher. Residuals allowed to follow a first-order auto-regressive process. Source: Store level scanner data-set. 
Table XII: Regression Results for Family Yogurt Category

\begin{tabular}{|c|c|c|c|c|c|}
\hline & All & $\begin{array}{l}\text { Income } \\
\text { Group } 1 \\
\end{array}$ & $\begin{array}{l}\text { Income } \\
\text { Group } 2 \\
\end{array}$ & $\begin{array}{l}\text { Income } \\
\text { Group } 3 \\
\end{array}$ & $\begin{array}{l}\text { Income } \\
\text { Group } 4 \\
\end{array}$ \\
\hline \multicolumn{6}{|c|}{ Dependent Var: In(Percent sold on sale) } \\
\hline Ln(Gasoline price) & $\begin{array}{c}0.252^{* *} \\
(0.040)\end{array}$ & $\begin{array}{l}0.359 * * \\
(0.085)\end{array}$ & $\begin{array}{l}0.234^{* *} \\
(0.076)\end{array}$ & $\begin{array}{l}0.283^{* *} \\
(0.079)\end{array}$ & $\begin{array}{l}0.164^{*} \\
(0.078)\end{array}$ \\
\hline Num. Items on Sale & $\begin{array}{l}8.924 * * \\
(0.049)\end{array}$ & $\begin{array}{c}8.769 * * \\
(0.102)\end{array}$ & $\begin{array}{l}8.916^{* *} \\
(0.095)\end{array}$ & $\begin{array}{l}8.747^{* *} \\
(0.095)\end{array}$ & $\begin{array}{c}9.289 * * \\
(0.097)\end{array}$ \\
\hline \multicolumn{6}{|l|}{ Num. Items on Sale } \\
\hline Squared & $\begin{array}{l}-7.198 * * \\
(0.054)\end{array}$ & $\begin{array}{l}-7.112 * * \\
(0.112)\end{array}$ & $\begin{array}{l}-7.192 * * \\
(0.104)\end{array}$ & $\begin{array}{l}-7.094^{* *} \\
(0.106)\end{array}$ & $\begin{array}{c}-7.416^{* *} \\
(0.109)\end{array}$ \\
\hline $\begin{array}{l}\text { Mean Percent Sold on Sale } \\
\text { N Obs }\end{array}$ & $\begin{array}{l}0.503 \\
27540\end{array}$ & $\begin{array}{l}0.526 \\
6426\end{array}$ & $\begin{array}{l}0.509 \\
7344\end{array}$ & $\begin{array}{l}0.505 \\
6885\end{array}$ & $\begin{array}{l}0.472 \\
6885\end{array}$ \\
\hline \multicolumn{6}{|c|}{ Dependent Var: In(Quantity weighted price paid) } \\
\hline Ln(Gasoline price) & $\begin{array}{c}-0.072^{* *} \\
(0.010)\end{array}$ & $\begin{array}{c}-0.084^{* *} \\
(0.021)\end{array}$ & $\begin{array}{c}-0.085 * * \\
(0.019)\end{array}$ & $\begin{array}{l}-0.051 * * \\
(0.020)\end{array}$ & $\begin{array}{l}-0.075^{* *} \\
(0.020)^{* *}\end{array}$ \\
\hline Num. Items on Sale & $\begin{array}{c}-0.857^{* *} \\
(0.012)\end{array}$ & $\begin{array}{c}-0.837 * * \\
(0.025)\end{array}$ & $\begin{array}{l}-0.815 * * \\
(0.022)\end{array}$ & $\begin{array}{c}-0.849 * * \\
(0.024)\end{array}$ & $\begin{array}{l}-0.905^{* *} \\
(0.025)^{* *}\end{array}$ \\
\hline \multicolumn{6}{|l|}{ Num. Items on Sale } \\
\hline Squared & $\begin{array}{c}0.144^{* *} \\
(0.013)\end{array}$ & $\begin{array}{c}0.184 * * \\
(0.028)\end{array}$ & $\begin{array}{l}0.135^{* *} \\
(0.025)\end{array}$ & $\begin{array}{l}0.094 * * \\
(0.027)\end{array}$ & $\begin{array}{c}0.125^{* *} \\
(0.028)\end{array}$ \\
\hline Mean Qt. Weighted Price & 0.730 & 0.710 & 0.720 & 0.740 & 0.760 \\
\hline N Obs & 27540 & 6426 & 7344 & 6885 & 6885 \\
\hline \multicolumn{6}{|l|}{ Other Controls: } \\
\hline Regional time trends & $\mathrm{Y}$ & $\mathrm{Y}$ & $\mathrm{Y}$ & $\mathrm{Y}$ & $\mathrm{Y}$ \\
\hline Regional month effects & $\mathrm{Y}$ & $\mathrm{Y}$ & $\mathrm{Y}$ & $\mathrm{Y}$ & $\mathrm{Y}$ \\
\hline Holidays & $\mathrm{Y}$ & $\mathrm{Y}$ & $\mathrm{Y}$ & $\mathrm{Y}$ & $\mathrm{Y}$ \\
\hline Store fixed effects & $\mathrm{Y}$ & $\mathrm{Y}$ & $\mathrm{Y}$ & $\mathrm{Y}$ & $\mathrm{Y}$ \\
\hline N Stores & 180 & 42 & 48 & 45 & 45 \\
\hline
\end{tabular}

Notes: Standard errors are in parentheses, * denotes statistical significance at the 5\% level or higher, ** denotes statistical significance at $1 \%$ level or higher. Residuals allowed to follow a first-order auto-regressive process. Source: Store level scanner data-set. 
Table XIII: Regression Results for Chicken Category

\begin{tabular}{|c|c|c|c|c|c|}
\hline & All & $\begin{array}{l}\text { Income } \\
\text { Group } 1 \\
\end{array}$ & $\begin{array}{l}\text { Income } \\
\text { Group } 2 \\
\end{array}$ & $\begin{array}{l}\text { Income } \\
\text { Group } 3 \\
\end{array}$ & $\begin{array}{l}\text { Income } \\
\text { Group } 4 \\
\end{array}$ \\
\hline \multicolumn{6}{|c|}{ Dependent Var: In(Percent sold on sale) } \\
\hline Ln(Gasoline price) & $\begin{array}{l}0.491 * * \\
(0.055)\end{array}$ & $\begin{array}{c}0.548 * * \\
(0.129)\end{array}$ & $\begin{array}{l}0.522 * * \\
(0.110)\end{array}$ & $\begin{array}{c}0.475 * * \\
(0.111)\end{array}$ & $\begin{array}{r}0.445 * * \\
(0.091)\end{array}$ \\
\hline Num. Items on Sale & $\begin{array}{l}3.247 * * \\
(0.062)\end{array}$ & $\begin{array}{l}3.523 * * \\
(0.141)\end{array}$ & $\begin{array}{l}3.001^{* *} \\
(0.123)\end{array}$ & $\begin{array}{l}3.424^{* *} \\
(0.128)\end{array}$ & $\begin{array}{r}3.123 * * \\
(0.106)\end{array}$ \\
\hline Num. Items Sale Squared & $\begin{array}{c}-2.257 * * \\
(0.080)\end{array}$ & $\begin{array}{c}-2.402 * * \\
(0.176)\end{array}$ & $\begin{array}{l}-2.011^{* *} \\
(0.161)\end{array}$ & $\begin{array}{c}-2.481^{* *} \\
(0.164)\end{array}$ & $\begin{array}{c}-2.239 * * \\
(0.138)\end{array}$ \\
\hline $\begin{array}{l}\text { Mean Percent Sold on Sale } \\
\text { N Obs }\end{array}$ & $\begin{array}{l}0.603 \\
27322\end{array}$ & $\begin{array}{l}0.632 \\
6372\end{array}$ & $\begin{array}{c}0.610 \\
7281\end{array}$ & $\begin{array}{l}0.59 \\
6836\end{array}$ & $\begin{array}{l}0.580 \\
6833\end{array}$ \\
\hline \multicolumn{6}{|c|}{ Dependent Var: In(Quantity weighted price paid) } \\
\hline Ln(Gasoline price) & $\begin{array}{c}-0.103^{* *} \\
(0.022)\end{array}$ & $\begin{array}{l}-0.075 \\
-0.046\end{array}$ & $\begin{array}{l}-0.095^{*} \\
(0.044)\end{array}$ & $\begin{array}{c}-0.153 * * \\
(0.044)\end{array}$ & $\begin{array}{l}-0.089 * \\
(0.041)\end{array}$ \\
\hline Num. Items on Sale & $\begin{array}{c}-0.438 * * \\
(0.025)\end{array}$ & $\begin{array}{c}-0.543 * * \\
(0.052)\end{array}$ & $\begin{array}{c}-0.423 * * \\
(0.051)\end{array}$ & $\begin{array}{c}-0.501^{* *} \\
(0.051)\end{array}$ & $\begin{array}{c}-0.315^{* *} \\
(0.047)\end{array}$ \\
\hline Num. Items Sale Squared & $\begin{array}{l}0.098 * * \\
(0.032)\end{array}$ & $\begin{array}{c}0.113 \\
-0.066\end{array}$ & $\begin{array}{c}0.061 \\
-0.067\end{array}$ & $\begin{array}{l}0.161^{*} \\
(0.066)\end{array}$ & $\begin{array}{c}0.100 \\
(0.061)\end{array}$ \\
\hline $\begin{array}{l}\text { Mean Qt. Weighted Price } \\
\text { N Obs }\end{array}$ & $\begin{array}{l}2.368 \\
27539\end{array}$ & $\begin{array}{l}2.050 \\
6426\end{array}$ & $\begin{array}{l}2.319 \\
7344\end{array}$ & $\begin{array}{l}2.388 \\
6884\end{array}$ & $\begin{array}{l}2.697 \\
6885\end{array}$ \\
\hline Other Controls: & & & & & \\
\hline Regional time trends & $\mathrm{Y}$ & $\mathrm{Y}$ & $\mathrm{Y}$ & $\mathrm{Y}$ & $\mathrm{Y}$ \\
\hline Regional month effects & $\mathrm{Y}$ & $\mathrm{Y}$ & $\mathrm{Y}$ & $\mathrm{Y}$ & $\mathrm{Y}$ \\
\hline Holidays & $\mathrm{Y}$ & $\mathrm{Y}$ & $\mathrm{Y}$ & $\mathrm{Y}$ & $\mathrm{Y}$ \\
\hline Store Fixed effects & $\mathrm{Y}$ & $\mathrm{Y}$ & $\mathrm{Y}$ & $\mathrm{Y}$ & $\mathrm{Y}$ \\
\hline N Stores & 180 & 42 & 48 & 45 & 45 \\
\hline
\end{tabular}

Notes: Standard errors are in parentheses, * denotes statistical significance at the $5 \%$ level or higher, ** denotes statistical significance at $1 \%$ level or higher. Residuals allowed to follow a first-order auto-regressive process. Source: Store level scanner data-set. 
Table XIV: Regression Results for Fresh Orange Juice Category

\begin{tabular}{|c|c|c|c|c|c|}
\hline & All & $\begin{array}{l}\text { Income } \\
\text { Group } 1 \\
\end{array}$ & $\begin{array}{l}\text { Income } \\
\text { Group } 2 \\
\end{array}$ & $\begin{array}{l}\text { Income } \\
\text { Group } 3 \\
\end{array}$ & $\begin{array}{l}\text { Income } \\
\text { Group } 4 \\
\end{array}$ \\
\hline \multicolumn{6}{|c|}{ Dependent Var: In(Percent sold on sale) } \\
\hline Ln(Gasoline price) & $\begin{array}{l}0.103^{* *} \\
(0.007)\end{array}$ & $\begin{array}{c}0.075^{* *} \\
(0.016)\end{array}$ & $\begin{array}{l}0.103^{* *} \\
(0.013)\end{array}$ & $\begin{array}{l}0.103^{* *} \\
(0.014)\end{array}$ & $\begin{array}{c}0.131^{* *} \\
(0.014)\end{array}$ \\
\hline Num. Sale Items & $\begin{array}{l}1.227^{* *} \\
(0.027)\end{array}$ & $\begin{array}{l}1.206^{* *} \\
(0.057)\end{array}$ & $\begin{array}{l}1.262^{* *} \\
(0.050)\end{array}$ & $\begin{array}{l}1.181^{* *} \\
(0.054)\end{array}$ & $\begin{array}{l}1.235^{* *} \\
(0.054)\end{array}$ \\
\hline Num. Sale Items Squared & $\begin{array}{c}-0.747 * * \\
(0.027)\end{array}$ & $\begin{array}{c}-0.737 * * \\
(0.058)\end{array}$ & $\begin{array}{c}-0.777 * * \\
(0.051)\end{array}$ & $\begin{array}{c}-0.697 * * \\
(0.055)\end{array}$ & $\begin{array}{c}-0.755^{* *} \\
(0.056)\end{array}$ \\
\hline Mean Percent Sold on Sale & 0.829 & 0.835 & 0.830 & 0.834 & 0.818 \\
\hline N Obs & 27540 & 6426 & 7344 & 6885 & 6885 \\
\hline \multicolumn{6}{|c|}{ Dependent Var: In(Quantity weighted price paid) } \\
\hline Ln(Gasoline price) & $\begin{array}{c}-0.109 * * \\
(0.008)\end{array}$ & $\begin{array}{c}-0.101^{* *} \\
(0.018)\end{array}$ & $\begin{array}{l}-0.116^{* *} \\
(0.016)\end{array}$ & $\begin{array}{c}-0.106 * * \\
(0.016)\end{array}$ & $\begin{array}{c}-0.110^{* *} \\
(0.016)\end{array}$ \\
\hline Num. Sale Items & $\begin{array}{c}-0.206 * * \\
(0.032)\end{array}$ & $\begin{array}{l}-0.166^{*} \\
(0.067)\end{array}$ & $\begin{array}{c}-0.244^{* * *} \\
(0.061)\end{array}$ & $\begin{array}{l}-0.123 \\
-0.063\end{array}$ & $\begin{array}{c}-0.289 * * \\
(0.067)\end{array}$ \\
\hline Num. Sale Items Squared & $\begin{array}{l}0.227 * * \\
(0.033)\end{array}$ & $\begin{array}{l}0.230^{* *} \\
(0.068)\end{array}$ & $\begin{array}{l}0.276^{* *} \\
(0.062)\end{array}$ & $\begin{array}{c}0.117 \\
-0.065\end{array}$ & $\begin{array}{l}0.284^{* *} \\
(0.069)\end{array}$ \\
\hline $\begin{array}{l}\text { Mean Qt. Weighted Price } \\
\text { N Obs }\end{array}$ & $\begin{array}{l}3.102 \\
27540\end{array}$ & $\begin{array}{l}3.032 \\
6426\end{array}$ & $\begin{array}{c}3.079 \\
7344\end{array}$ & $\begin{array}{l}3.124 \\
6885\end{array}$ & $\begin{array}{l}3.166 \\
6885\end{array}$ \\
\hline Other Controls: & & & & & \\
\hline Regional time trends & $\mathrm{Y}$ & $\mathrm{Y}$ & $\mathrm{Y}$ & $\mathrm{Y}$ & $\mathrm{Y}$ \\
\hline Regional month effects & $\mathrm{Y}$ & $\mathrm{Y}$ & $\mathrm{Y}$ & $\mathrm{Y}$ & $\mathrm{Y}$ \\
\hline Holidays & $\mathrm{Y}$ & $\mathrm{Y}$ & $\mathrm{Y}$ & $\mathrm{Y}$ & $\mathrm{Y}$ \\
\hline Store Fixed effects & $\mathrm{Y}$ & $\mathrm{Y}$ & $\mathrm{Y}$ & $\mathrm{Y}$ & $\mathrm{Y}$ \\
\hline N Stores & 180 & 42 & 48 & 45 & 45 \\
\hline
\end{tabular}

Notes: Standard errors are in parentheses, * denotes statistical significance at the $5 \%$ level or higher, ** denotes statistical significance at $1 \%$ level or higher. Residuals allowed to follow a first-order auto-regressive process. Source: Store level scanner data-set. 
Table XV: Effect of Gasoline Prices on Total Volume Sold and Total Revenues

\begin{tabular}{|c|c|c|c|c|}
\hline & Cereal & Yogurt & Chicken & Orange Juice \\
\hline \multicolumn{5}{|c|}{ Dependent Var: In(Total quantity sold)* } \\
\hline Ln(Gasoline price) & $\begin{array}{c}0.374 * * \\
(0.033)\end{array}$ & $\begin{array}{c}0.819 * * \\
(0.035)\end{array}$ & $\begin{array}{c}0.842 * * \\
(0.039)\end{array}$ & $\begin{array}{l}0.435^{* *} \\
(0.033)\end{array}$ \\
\hline Num. Items on Sale & $\begin{array}{l}1.507^{* *} \\
(0.066)\end{array}$ & $\begin{array}{l}1.638 * * \\
(0.033)\end{array}$ & $\begin{array}{c}0.463^{* *} \\
(0.053)\end{array}$ & $\begin{array}{l}0.269 * * \\
(0.065)\end{array}$ \\
\hline $\begin{array}{l}\text { Num. Items on Sale } \\
\text { Squared }\end{array}$ & $\begin{array}{c}-1.327 * * \\
(0.092)\end{array}$ & $\begin{array}{c}-0.370^{* *} \\
(0.036)\end{array}$ & $\begin{array}{c}-0.239 * * \\
(0.069)\end{array}$ & $\begin{array}{c}-0.471^{* *} \\
(0.066)\end{array}$ \\
\hline \multicolumn{5}{|c|}{ Dependent Var: In(Total net revenues) } \\
\hline Ln(Gasoline price) & $\begin{array}{l}0.299 * * \\
(0.028)\end{array}$ & $\begin{array}{c}0.584 * * \\
(0.033)\end{array}$ & $\begin{array}{c}0.896 * * \\
(0.037)\end{array}$ & $\begin{array}{l}0.117 * * \\
(0.029)\end{array}$ \\
\hline Num. Items on Sale & $\begin{array}{l}0.910^{* *} \\
(0.049)\end{array}$ & $\begin{array}{c}0.801^{* *} \\
(0.025)\end{array}$ & $\begin{array}{c}0.028 \\
(0.036)\end{array}$ & $\begin{array}{l}0.321^{* *} \\
(0.046)\end{array}$ \\
\hline $\begin{array}{l}\text { Num. Items on Sale } \\
\text { Squared }\end{array}$ & $\begin{array}{c}-0.870 * * \\
(0.068)\end{array}$ & $\begin{array}{c}-0.258 * * \\
(0.027)\end{array}$ & $\begin{array}{c}-0.280 * * \\
(0.047)\end{array}$ & $\begin{array}{c}-0.443^{* *} \\
(0.047)\end{array}$ \\
\hline $\begin{array}{l}\text { Other Controls: } \\
\text { Regional time trends }\end{array}$ & $\mathrm{Y}$ & $\mathrm{Y}$ & $\mathrm{Y}$ & $\mathrm{Y}$ \\
\hline Regional month effects & $\mathrm{Y}$ & $\mathrm{Y}$ & $\mathrm{Y}$ & $\mathrm{Y}$ \\
\hline Holidays & $\mathrm{Y}$ & $\mathrm{Y}$ & $\mathrm{Y}$ & $\mathrm{Y}$ \\
\hline Store fixed effects & $\mathrm{Y}$ & $\mathrm{Y}$ & $\mathrm{Y}$ & $\mathrm{Y}$ \\
\hline N Stores & 180 & 180 & 180 & 180 \\
\hline N Obs & 27540 & 27540 & 27539 & 27540 \\
\hline
\end{tabular}

Notes: Standard errors are in parentheses, * denotes statistical significance at the $5 \%$ level or higher, ${ }^{* *}$ denotes statistical significance at $1 \%$ level or higher. Residuals allowed to follow a first-order auto-regressive process. Source: Store level scanner data-set. Note that for Total Revenues, sample size drops to 27539 for the Chicken category only. *Total quantity sold is in appropriate units for each category (e.g. pounds for chicken, and six ounce cups for yogurt). 
Figure I: Weekly Gasoline and Crude Oil Prices for 2001- 2006

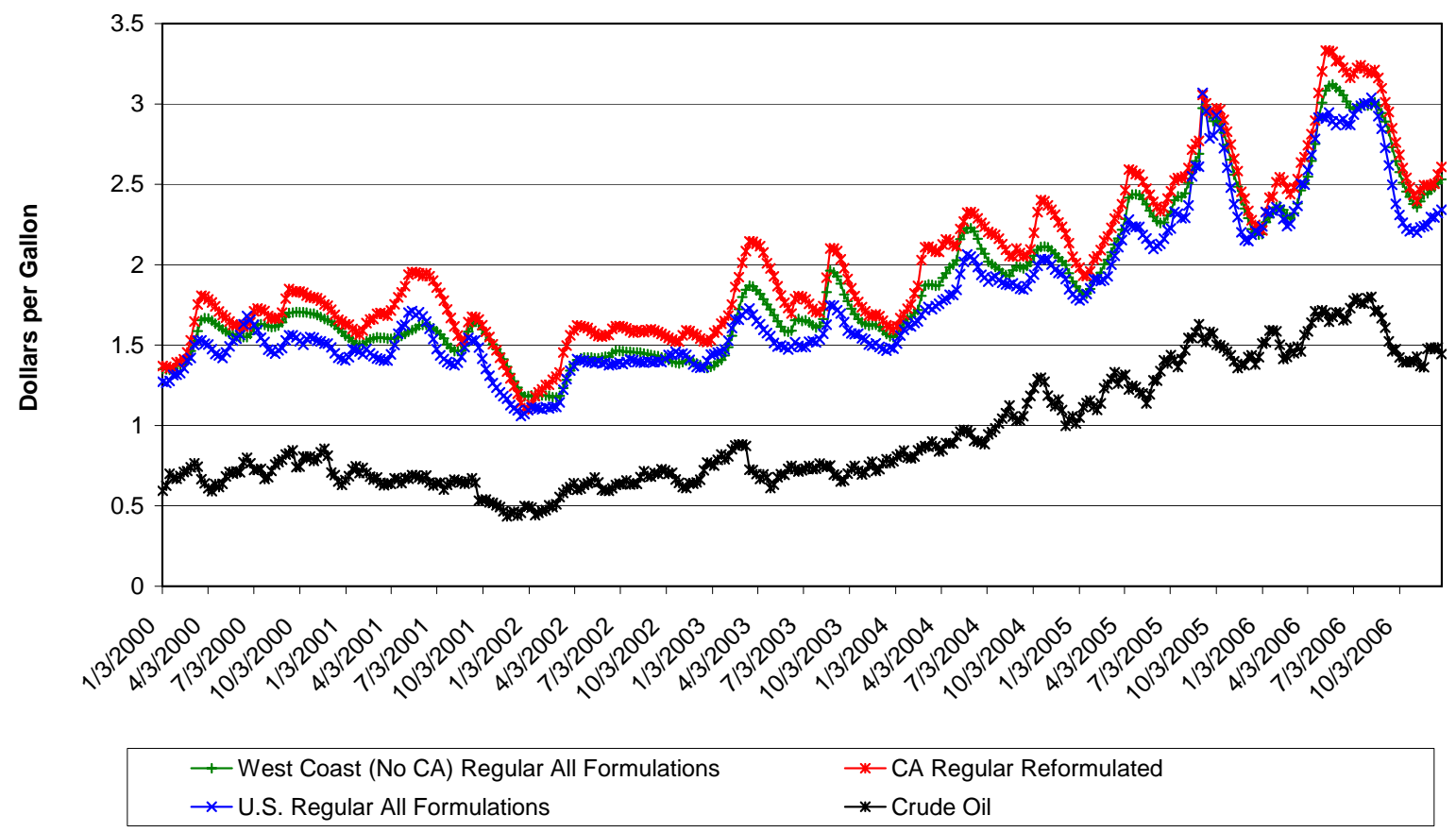


Figure II: Smoothed Regression Line of Regression Residuals for

Percent of Cereal Sold On Sale and Retail Gasoline Prices
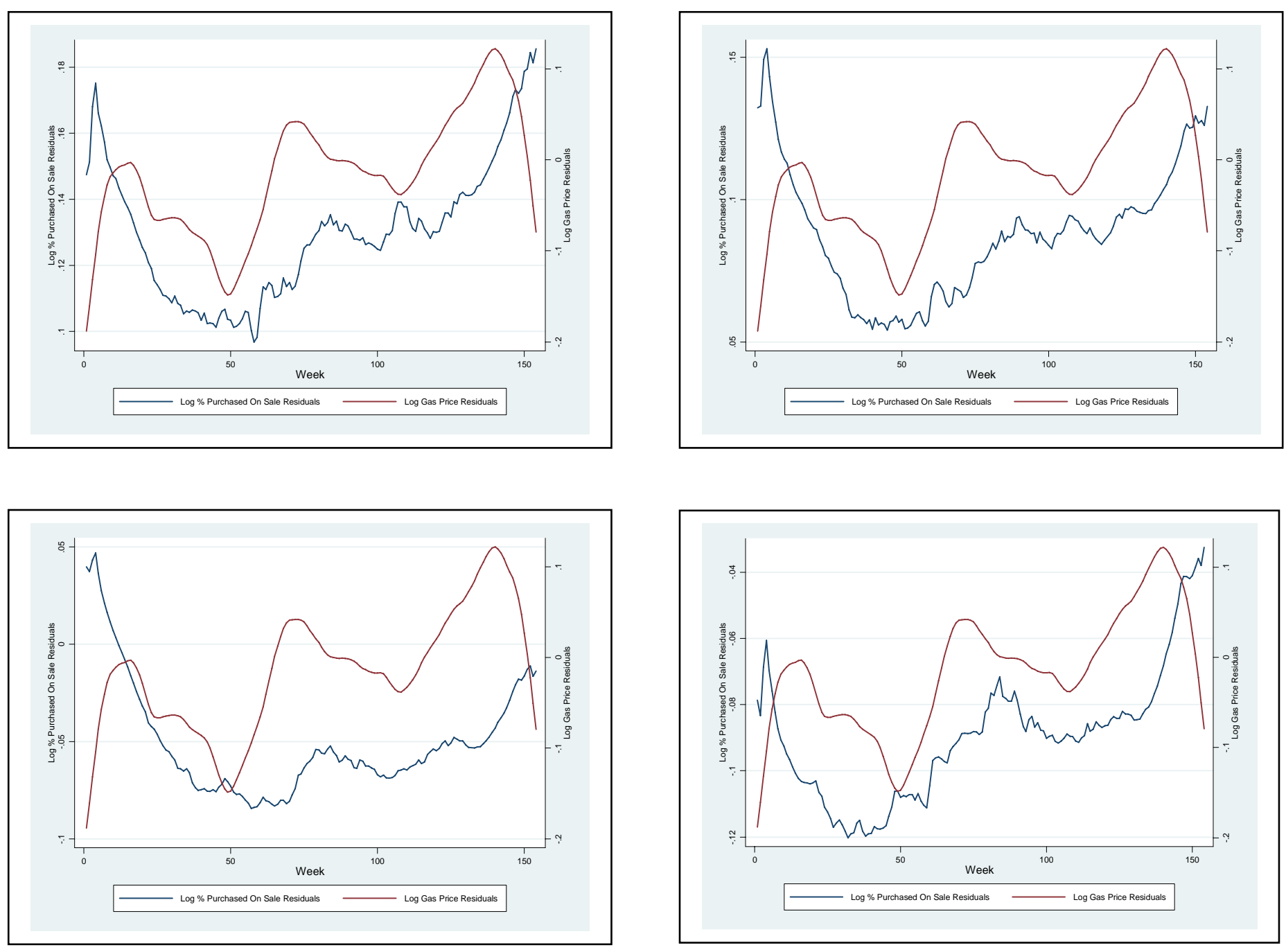